\title{
FISSIDENS SUBGENUS ALOMA (BRYOPHYTA) IN TROPICAL AFRICA I. THE LARGE-CELLED COSTATE AND ECOSTATE SPECIES
}

\author{
Maria Alida Bruggeman-Nannenga
}

\begin{abstract}
A revision of the large-celled costate and ecostate species of Fissidens subgenus Aloma Kindb. from tropical Africa is presented. Fissidens flaccidus var. mammillosus Brugg.-Nann. var. nov. is described and the Neotropical F. mollis Mitt. is reinstated. Most African specimens previously identified as F. enervis Sim are referred to Fissidens dealbatus Hook. f. \& Wilson, a new indigene for Africa. Fissidens molliculus P. de la Varde, F. hedbergii P. de la Varde and F. hookerioides Bizot \& Onr. in Bizot are subsumed under F. dealbatus. Fissidens enervis s.str. appeared to be a rare species. The distributions in O'Shea (2006) are revised, updated and, when necessary, amended. Fissidens flaccidus Mitt. is for the first time reported from South Africa and Guinea, F. zollingeri Mont. from Ghana, F. grandifolius Broth. \& P. de la Varde from Cameroon and F. usambaricus Broth. from Malawi and Gabon. Pending further research, F. palmatus Hedw. is excluded from the African bryoflora. It is stressed that, since vegetative and perichaetial stems are different, perichaetial stems (and leaves of perichaetial stems) are to be compared with perichaetial stems (and leaves of perichaetial stems), whereas vegetative stems (and leaves of vegetative stems) should be compared with other vegetative stems (and leaves of vegetative stems).
\end{abstract}

Key words: distribution, Fissidens, large-celled Aloma, taxonomic revision, tropical Africa

Maria Alida Bruggeman-Nannenga, Griffensteijnseplein 23, NL 3703 BE Zeist, The Netherlands

\section{INTRODUCTION}

Fissidens subgenus Aloma Kindb. embraces a wide range of gametophytic types (Pursell \& Bruggeman-Nannenga 2004). Five not sharply distinct groups can be recognized: one without costa, one with large (over $30 \mu \mathrm{m}$ long) cells, one with pluripapillose cells, one with unipapillose cells and one with smooth cells. Because of the existence of transitional species, these groups are no longer recognized as taxa (Pursell \& Bruggeman-Nannenga 2004). Fissidens subgenus Aloma includes elimbate, semilimbate and a few completely limbate species, and the laminal cells are small, mediumsized or large. Ecostate species as well as species with large (30 $\mu \mathrm{m}$ long or more) laminal cells are restricted to this subgenus. A notable exception is the African $F$. subgenus Fissidens Hedw. species F. magnicellulatus Brugg.-Nann., which also has cells $30 \mu \mathrm{m}$ long or more. This species is therefore included in the key below. All ecostate species have large cells but not all large-celled species are ecostate (Pursell \& Bruggeman-Nannenga
2004). The present paper is a revision of those tropical African species of subgenus Aloma that have large (longer than $30 \mu \mathrm{m}$ ), smooth laminal cells. It includes both costate and ecostate species. In one species, F. zollingeri Mont., large cells are restricted to the vaginant lamina. With the exception of $F$. usambaricus Broth., all included species are limbate. Apart from their large cells, limbate, costate species bear a strong resemblance to subgenus Fissidens, which is characterized by limbate leaves and smooth laminal cells but has small to medium-sized cells and a different sporophyte.

This paper follows the classification by Pursell and Bruggeman-Nannenga (2004), who emphasized sporophytic characters. They considered large-celled limbate species to belong in subgenus Aloma, as they have Aloma sporophytes, ${ }^{1}$ and classified limbate species with small, smooth cells

\footnotetext{
1 Capsule with \pm 32 columns of exothecial cells and a scariosus-type peristome.
} 
in subgenus Fissidens because of their subgenus Fissidens sporophytes. ${ }^{2}$ Suzuki and Iwatsuki (2007, 2012), on the other hand, emphasized gametophytic characters. They classified ecostate species in subgenus Aneuron Kindb., and limbate, costate species with smooth cells, regardless of cell size and sporophytic characters, in subgenus Fissidens. It will be interesting to learn what fresh characters such as DNA will contribute to this question.

During this revision some challenging differences were found between the data in the monograph on Neotropical Fissidentaceae (Pursell 2007) and what is seen in Africa. Some of these have resulted in taxonomic decisions. A problem concerning F. palmatus Hedw. and F. grandifolius Broth. \& P. de la Varde is discussed, but remains unsolved; hopefully this discussion will stimulate further research.

\section{Practical REMARKS}

It is self-evident that morphological taxonomic research needs to be based on comparisons of equivalent characters. In Fissidens the vegetative and perichaetial stems are different and have different leaves. Therefore, perichaetial stems (and leaves of perichaetial stems) are to be compared with perichaetial stems (and leaves of perichaetial stems), whereas vegetative stems (and leaves of vegetative stems) should be compared with other vegetative stems (and leaves of vegetative stems). In medium-sized and long stems all mid leaves have more or less the same shape and size. This makes such leaves most suitable for comparison. In short stems the leaf size increases rapidly up the stem, so comparison of these with leaves of longer stems will be problematic. One also needs to be cautious when comparing laminal cells. Nearness to the costa, the stem and the limbidium induces differentiation (cells become larger, more oblong and less ornamented). Moreover, whereas inner cells of the dorsal and apical lamina are similar, inner vaginant laminal cells tend to differ.

The 'distributions' in the present paper are supported by specimens examined for this paper or

\footnotetext{
2 Capsule with 40 or more columns of exothecial cells and
} a bryoides-type peristome. else their source is indicated. Distributions of some species are extended and/or had to be amended. No differentiation is made between the terms 'mammillose' and 'unipapillose'. Trans-sections of these large-celled species are best examined in $5 \% \mathrm{KOH}$, which makes them swell beautifully.

\section{KEY}

1. Leaves $( \pm)$ ecostate . . . . . . . . . . . . 2

1. Leaves with distinct costa . . . . . . . . . 5 5

2. Leaves elimbate ........ 4. F. usambaricus

2. Leaves limbate . . . . . . . . . . . . . . 3

3. Limbidial cells $5-12 \mu \mathrm{m}$ wide, limbidium ill-defined .................. F. metzgeria

3. Limbidial cells narrower, $\pm 1 \mu \mathrm{m}$ wide, limbidium distinct $\ldots \ldots \ldots \ldots \ldots \ldots \ldots \ldots \ldots$

4. Capsule with 32 columns of exothecial cells, limbidia 1-2-stratose .......... 2. F. enervis

4. Capsule with 40 or more columns of exothecial cells, limbidia 1-7-stratose.... . 1. F. dealbatus

5. Mid dorsal laminal cells small, (6.5-)11.0-27.0 $\times$ 4.5-14.5(-19.5) $\mu \mathrm{m}$.......... 9. F. zollingeri

5. At least some mid dorsal laminal cells $30 \mu \mathrm{m}$ or longer $\ldots \ldots \ldots \ldots \ldots \ldots \ldots \ldots$

6. Costa ending well below apex $\ldots \ldots \ldots \ldots 7$

6 . Costa reaching apex .............. 9

7. Laminal cells mammillose $\ldots \ldots \ldots \ldots \ldots \ldots$ ..........5b. F. flaccidus var. mammillosus

7. Laminal cells smooth . . . . . . . . . . . . . 8

8. Stems mostly short, palmate; capsules inclined; antheridia axillary and on tiny stems at base of perichaetial stems; limbidia weakly 1(-2)-stratose on mid dorsal lamina . . . . 6. F. grandifolius

8. Stems longer, with pinnately arranged leaves; capsules rare, erect; antheridia rare, terminal; limbidia stronger, (1-)2-stratose on mid dorsal lamina ...

5a. F. flaccidus var. flaccidus

9. Limbidia not reaching leaf apex, intramarginal on all laminae ............. 8. Figerianus

9. Limbidia reaching leaf apex, marginal on dorsal and apical lamina ................ 10

10. Leaves distant, peristome bryoides-type, \pm 40 columns of exothecial cells on theca

F. magnicellulatus $^{3}$

10. Leaves crowded, peristome scariosus-type, \pm 32 columns of exothecial cells on theca

7. F. minutifolius

\footnotetext{
3 Not included in this paper. Description and figures in Bruggeman-Nannenga (2013a, b).
} 


\section{ECOSTATE SPECIES}

Ecostate species represent a remarkable gametophytic group within subgenus Aloma, with large laminal cells and with central strands lacking or weakly developed. These species appear ecostate, yet many have or can have vestigial costae (Salmon 1899; Pursell \& Bruggeman-Nannenga 2004) which occasionally can reach as far as the length of the vaginant lamina (e.g., in Müller Z215, $F$. usambaricus and the lectotype F. enervis $\mathrm{Sim}$ ). Such weak costae have the same arrangement of cells as the bryoides-type costa with two large adaxial and one large central cell, but differ from well-developed bryoides-type costae in having thinner cell walls and absent or poorly developed lateral bands. Thus the ecostate species are not sharply distinct from the costate species. Ecostate species resemble costate subgenus Aloma species with large inflated cells. Many of these have costae that are short for the genus (Pursell \& Bruggeman-Nannenga 2004). Like other subgenus Aloma species, ecostate species typically have capsules with \pm 32 columns of exothecial cells and scariosus-type peristomes (Pursell \& BruggemanNannenga 2004).

It is interesting that not only the laminal cells but all or most gametophytic cells (e.g., cortical cells of the stem and cells of the calyptra) are inflated, whereas sporophytic cells are not. Limbidial cells are inflated in some species (e.g., F. metzgeria), but not in, for example, F. dealbatus, $F$. enervis and $F$. hyalinus Wilson \& Hook.

Ecostate species can form dense mats but they frequently grow scattered among other mosses.

\section{Fissidens dealbatus Hook. f. \& Wilson}

Fig. 1

in Wilson in Hook. f., Fl. Nov.-Zel. 2: 63, pl. LXXXIV-2. 1854; Schistophyllum dealbatum (Hook. f. \& Wilson) Lindb., Utkast Eur. Bladmoss.: 16. 1878 - TYPE (PROTOLOGUE): NEW ZEALAND, Northern Island, Bay of Islands, Hooker [J. D. H.] - HOLOTYPE as Wilson 318 (BM!).

Fissidens molliculus P. de la Varde, Rev. Bryol. Lichenol. 7: 227, f. 1. 1935 - Protologue: CENTRAL AFRICAN REPUBLIC [Oubangui], Ravin de la savanne à l'Ouest de Bozoum, sur terre sabloneuse,
III 1933, Tisserant - TyPE labels: Oubangui, ravin en savanne, Bozoum ouest, III 1933. Tisserant 649 (HOLOTYPE: PC-PV!; ISOTYPE BM, same label but s.n!), syn. nov.

Fissidens hedbergii P. de la Varde, Ark. Bot., n.s. 3: 129, f. 1: a-c. 1955 [1957]; F. enervis subsp. hedbergii (P. de la Varde) Bizot in Bizot \& Pócs, Acta Bot. Acad. Sci. Hung. 25: 239. 1979 - Protologue: TANZANIA, Mt. Kilimanjaro, montane rainforest above Marangu, $2100 \mathrm{~m}$, on the ground at the path towards Bismarck Hut, Hedberg 1144, p.p. - label: Tanzania, [Tanganyika Territory], Kilimandjaro mountain, rainforest above Marangu, on the ground at the path towards Bismarck Hut, 2000 m, Hedberg 1144A, p.p. (HOLOTYPE: PC-PV!; ISOTYPE: BM!), syn. nov.

Fissidens hookerioides Bizot \& Onr. in Bizot, Rev. Bryol. Lichénol. 42: 843. 1976 - Protologue: MADAGASCAR, Tananarive, domaine des Frères de Soavimbahoaka, sur latérite ombragée, 1400 m, 6 VII 1971, Onraedt 71/M/3137 (orthographic error) - label: as protologue except for the collection number which is 71/M/5137 (HOLOTYPE: PC-0096394!; ISOTYPE: BR!), syn. nov.

Stem in cross section without or with weakly developed central strand and 20-50 $\mu \mathrm{m}$ wide cortical cells, unbranched, with pinnately or, infrequently, elongated palmately arranged leaves, not heterocaulous, (1.5-)3.0-6.5 × 1.0-3.0 mm, browning in $\mathrm{KOH}$; rhizoids basal, colorless to pale brown, less often orange-brown, smooth; axillary nodules not differentiated; leaves typically distant, 6-10 leaf pairs, somewhat crispate when dry, elliptical with acute-acuminate or less often acute apex that ends in a narrow pointed cell, 0.9-2.3 $\times 0.2-0.6 \mathrm{~mm}, 2.5-5.0$ times as long as wide, limbate; limbidium on all laminae, confluent at leaf apex, confluent at apex of vaginant lamina or not, reaching insertion of dorsal lamina, almost to completely reaching insertion of vaginant lamina, in mid dorsal lamina (4.5-)6.0-19.0 $\mu \mathrm{m}$ wide, 1-7-stratose (see remark below), marginal; on vaginant laminae $6.5-11.0 \mu \mathrm{m}$ wide, $1-5$-stratose, marginal; vaginant lamina $1 / 3-3 / 5$ of leaf length, at insertion up to half as wide as stem, closed to \pm closed, unistratose; dorsal lamina wide, tapering and straight to slightly rounded towards insertion, typically reaching insertion, not decurrent; dorsal and apical lamina unistratose, rarely with isolated, 
unicellular bistratose dots; costa \pm lacking, in surface view sometimes visible as differentiated band alongside vaginant lamina; mid dorsal laminal cells hexagonal, 22.5-77.0 × 16.0-33.5 $(-48.0) \mu \mathrm{m}$, smooth, plane to inconspicuously bulging; mid vaginant laminal cells narrower, 45.0-95.0 $\times$ 12.0-30.5 $\mu \mathrm{m}$; no gemmae observed.

Fertile parts, perigonia and perichaetia terminal on separate plants in same collection. Perigonia terminal on 1.5-3.0 mm long perigonial plants; antheridia $210 \mu \mathrm{m}$ long; perichaetia terminal, perichaetial leaves 1.5-2.6 mm long; archegonia 200-290 $\mu \mathrm{m}$ long; calyptra tightly clasping operculum, scabrose, 0.6-0.8 mm long. Sporophyte. Seta 4-6 mm long, smooth, 1 per perichaetium; capsule symmetrical, $0.90-1.00 \times 0.40-0.55 \mathrm{~mm}$, 40-64 columns of oblong exothecial cells; peristome scariosus-type (basal part and filaments observed), teeth 56-60 $\mu \mathrm{m}$ wide at base; operculum rostrate, 0.8-0.9 mm long; spores $9.5-13.5 \mu \mathrm{m}$ diam., smooth.

Fissidens dealbatus is characterized by its thecae with 40-64 columns of exothecial cells (exceptionally high for subgenus Aloma), distinct, narrow, 1-7-stratose limbidia of narrow (lumina \pm $1 \mu \mathrm{m}$ wide) limbidial cells, ecostate leaves that are limbate on all laminae, and large laminal cells. The disparity between the large inflated laminal cells and the narrow limbidial cells in this species is striking. This is particularly clear in trans-sections (Fig. 1J, K-L). There is considerable variation in leaf shape and the length and width of the mid laminal cells. The type of $F$. hookerioides is a small expression with short, relatively wide leaves and \pm isodiametric cells. Fissidens dealbatus is most likely to be confused with $F$. hyalinus (not known from Africa) and F. enervis; like $F$. dealbatus, these species have large cells, ecostate, limbate leaves, and marked contrast between the large inflated laminal cells and narrow limbidial cells.
Fissidens dealbatus differs from both in the number of columns of exothecial cells ( 40 or more versus \pm 32 ) and thicker limbidia (unistratose in F. hyalinus - fide Iwatsuki \& Suzuki 1995 and 1-2-stratose in F. enervis). Furthermore, F. dealbatus and $F$. hyalinus have acute to acute acuminate leaf apices, whereas $F$. enervis has cuspidate ones. Many collections of this species are too small to make trans-sections of them, and capsules are often lacking. In such cases one has to resort to estimating the thickness of the limbidium, which is unreliable. The third ecostate, limbate African species, F. metzgeria, is easily distinguished by its ill-defined limbidium of wide cells and the frequent occurrence of characteristic, multicellular, epilaminal gemmae.

Remarks. Previously, F. molliculus (Bizot \& Pócs 1979) and F. hedbergii (BruggemanNannenga 1997) were considered to be $F$. enervis. Most specimens were re-examined during the preparation of the present paper. Many specimens earlier identified as $F$. enervis appeared to differ from that species by having limbidia thicker than 1-2 layers and in having 40 or more columns of exothecial cells (versus \pm 32 in F. enervis). Of the African material studied, only the type specimen could be retained in $F$. enervis. Comparison of tropical African collections with acute-acuminate apices, 40 or more columns of exothecial cells and pluristratose limbidia with F. dealbatus from New Zealand and Guadalcanal showed the African collections to be conspecific with $F$. dealbatus Hook. f. \& Wils.

No trans-sections were made of the type of $F$. hookerioides. Its limbidia were estimated to be pluristratose. Sporophytes were lacking.

In F. dealbatus the limbidia often 'fold' around the laminal cells and then are not truly pluristratose (e.g., Fig. 1L, which in the present paper has been interpreted as 7-stratose).

Fig. 1. Fissidens dealbatus Hook. f. \& Wilson. A - perichaetial plant, B \& C - leaves, D \& E - leaf apices, F - insertion of leaf, $\mathrm{G}$ - capsule and calyptra, $\mathrm{H}$ - trans-section of stem, I - trans-section of leaf with unistratose laminae, J - trans-section of dorsal lamina with bistratose dot, $\mathrm{K} \& \mathrm{~L}$ - trans-sections of vaginant lamina limbidia (K with 1-2-cells wide, 2-4-stratose limbidium; L with one-cell-wide, 7-stratose limbidium) - A, F, J from Pócs 9104/P; B, D, G-I, K, L from Müller B98; C from Pócs 8430A; E from Townsend 75/330. 


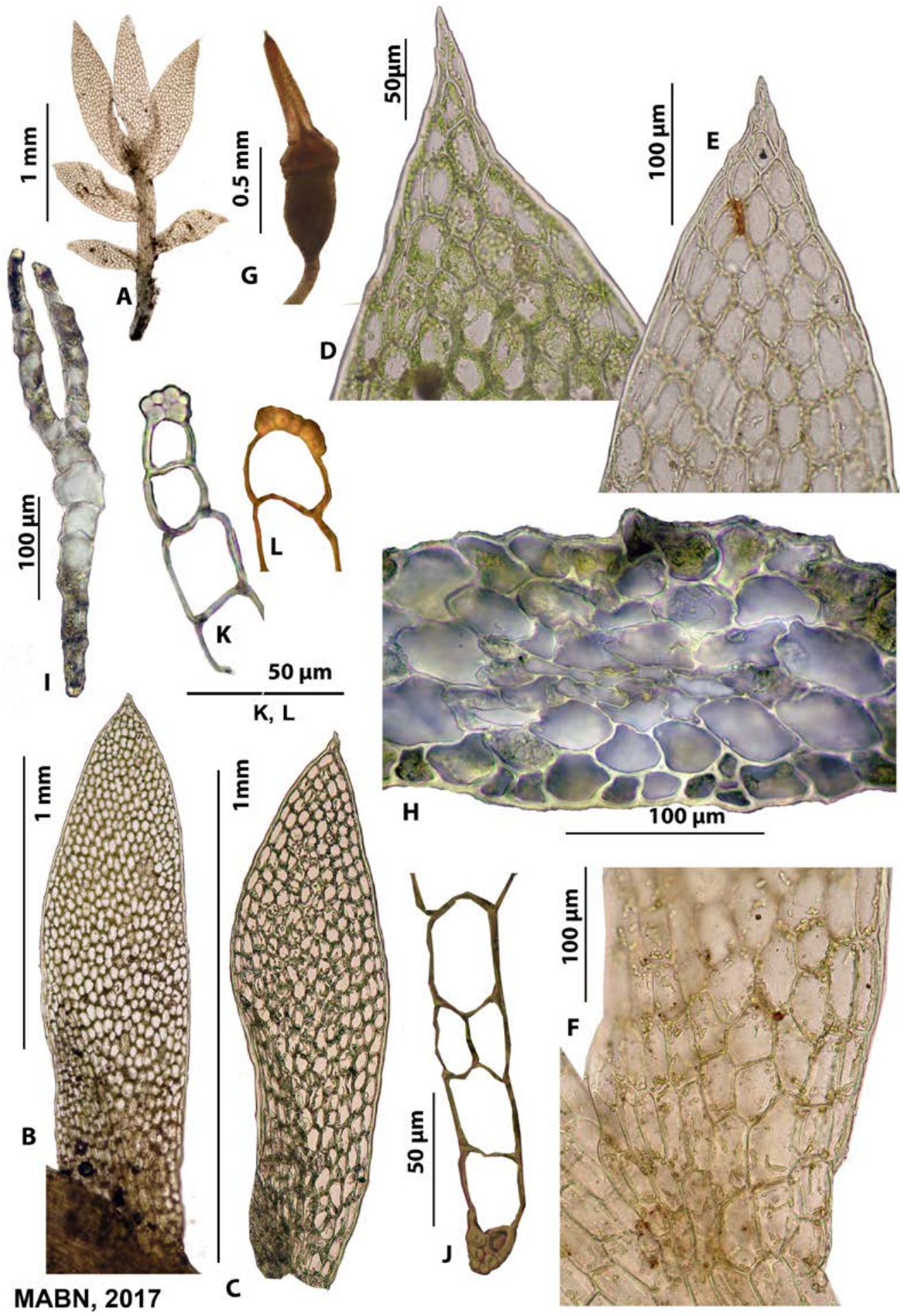


SUBSTRATE AND HABIT. On soil, rarely on rocks, once on soil-covered wood. Growing scattered among other mosses or less often in pure mats.

HABITAT. In all kinds of forests (montane rainforest, montane cloud forest, montane evergreen forest, mesic montane forest, submontane rainforest, bamboo forest); also collected in Philippia heath with remnants of montane evergreen forest and in a Eucalyptus plantation.

ElEvation. In Africa known from 950-2500 m a.s.1.; in New Zealand from 0-900 m a.s.l. (Beever et al. 2002).

Distribution. Fissidens dealbatus is widespread in tropical Africa. West tropical Africa (Bioko), west central tropical Africa (Central African Republic), east tropical Africa (Kenya, Rwanda, Tanzania, Uganda), south tropical Africa (Malawi) and western Indian Ocean (Madagascar). Outside Africa it is known from New Zealand, New Caledonia, Australia (Beever et al. 2002) and the New Hebrides (Iwatsuki \& Suzuki 1995).

Also recorded (as F. enervis) from the Democratic Republic of the Congo (O'Shea 2006), São Tomé and Príncipe (Shevock et al. 2013) and Zambia (O'Shea 2006). These are not included in the distribution since they may refer to $F$. dealbatus. A specimen from South Africa [Transvaal, Wolfspruit, Ofcolaco, Brenan M 3280A (E)] seems to be this species, but the material is too poor for certainty.

Selected SPeCimens eXAmined: CENTRAL AFRICAN REPUBLIC, type $F$. molliculus. - EQUATORIAL GUINEA, Bioko, $10 \mathrm{~km} \mathrm{~S}$ of Luba, Berg Caldera, $3^{\circ} 22^{\prime} \mathrm{N}, 8^{\circ} 32^{\prime} \mathrm{E}$, Müller B98, p.p. (DR, L). - MADAGASCAR, type $F$. hookerioides. - KENYA, Rift Valley Province, Trans Nzoia District, Cherangani, R.A. Maas Geesteranus $10313 a$ (L, a few stems). - MALAWI, S Escarpment of Zomba Plateau on the S slope of Kuchawe summit, Pócs 9171/BD (EGR, L, a few mixed with $F$. rotereaui $\mathrm{P}$ de la Varde). - RWANDA, Lac Bulera (au nord-est de Ruhengiri), rive nord du Lac, De Sloover 13.565, p.p., a few mixed with several other Fissidens species (L, a few stems). - TANZANIA,
Nguru Mountains in Morogoro District, watershed between Chogowale and Divue headwaters, $6 \mathrm{~km} \mathrm{SSE}$ of Maskati village, Kis \& Pócs 9129/Q (EGR, L); West Usambara Mts, E of Magila village, SW edge of Ndelemai F.R., Pócs 8430/A (EGR, L); Arusha National Park, E slopes of Meru Crater, along trails between Kitoto and Cabin at Njeku, $3^{\circ} 14^{\prime} \mathrm{S}, 34^{\circ} 47^{\prime} \mathrm{E}$, Crosby \& Crosby 11231 (MO, L); Mt. Meru, SW slope of Mt. Meru above Laikinoi, Pócs \& Ochyra $88147 / H$ (EGR, L). - UGANDA, Kibale NP, Research Forest, MUBFS, Kanyawara. $0^{\circ} 33^{\prime} \mathrm{N}, 30^{\circ} 21^{\prime} \mathrm{E}$, Wigginton $U$ $5285 A$ (E, L, a few mixed with Fissidens intramarginatus s.l. and a few F. zollingeri); Kisoro, Fitzgerald s.n. (PC). - NEW ZEALAND, North Island, South Auckland Land District, Te Kauri Scenic Reserve, $38^{\circ} 4^{\prime} 0^{\prime \prime} \mathrm{S}$, $174^{\circ} 59^{\prime} 0^{\prime \prime}$ E, Spragg 93 (AK, L). - GUADALCANAL, near camp at base of Mt. Popemanaseu, Van Zanten 682582 (GRO, L).

ILluSTRATIONS: Beever et al. (2002: 28; 2014: fig. 10), Bruggeman-Nannenga (2006a: fig. 7a-c, as F. enervis), Chuah-Petiot (2003: fig. 30, as $F$ enervis, but the shape of the apex indicates $F$. dealbatus rather than $F$. enervis), Salmon (1899: figs 13-15), Stone (1986: fig. 3), Seppelt \& Stone (2016: F. dealbatus).

\section{Fissidens enervis Sim}

Fig. 2

Trans. Roy. Soc. South Africa 15: 187, fig. 1926 - ProTOLOGUE: [SOUTH AFRICA], Natal, Town Bush Valley, Pietermaritzburg, 3000 ft, 1917, Sim 9899, Nottingham Road, Sim 8648 and Burgerstreet, Pietermaritzburg, Sim 9900 - LестотүPe (designated by Magill 1981) labeled: Distr. Pietermaritzburg, Town bush valley, 2500 feet, IV 1917, Sim 9899 (PRE!, ISOLECTOTYPE BM000871763!).

Stem in cross section without central strand (based on Indian specimen), unbranched, with pinnately arranged leaves (only fertile stems seen), $\pm 3.0 \times 1.0-2.5 \mathrm{~mm}$; rhizoids basal, from lower stem cortex and from apical part of lamina, hyaline or brown, smooth; leaves distant, to 7 pairs, crispate when dry, elliptical with cuspidate tip, $0.95-1.70 \times 0.25-0.40 \mathrm{~mm}, 3.5-5.0$ as long as wide, limbate; limbidium \pm confluent at leaf apex, confluent at apex of vaginant laminae, reaching insertion of dorsal lamina, in upper leaves ending well above insertion of vaginant lamina, in lower

Fig. 2. Fissidens enervis Sim. A - sporophytic stem, B - perigonial stem, C - leaf apex, D - detail of leaf apex with rhizoid growing from lamina, E - mid leaf, $\mathrm{F}$ - insertion of leaf, $\mathrm{G}$ - limbidium on mid dorsal lamina, $\mathrm{H}$ - capsule. All from type specimen. 


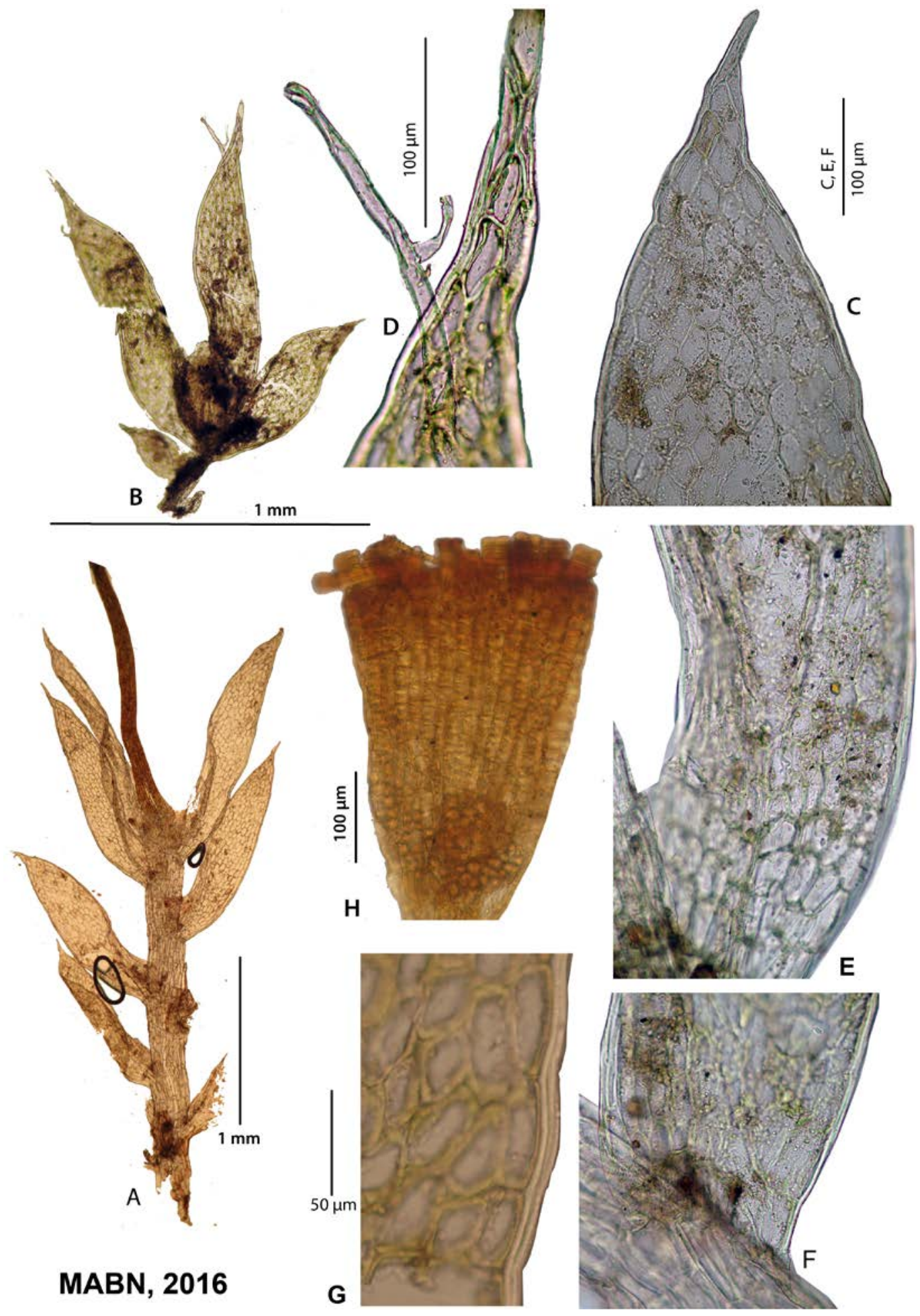


leaves sometimes reaching insertion, in mid dorsal lamina 7.5-14.5 $\mu \mathrm{m}$ wide, more than unistratose (estimated); on vaginant lamina, $20 \mu \mathrm{m}$ wide, 1-3-stratose (based on Indian specimen), marginal throughout; vaginant lamina ca 1/2 of leaf length, at base less wide than stem, slightly rounded at insertion, not decurrent, unistratose, subequal; dorsal lamina \pm straight towards insertion, reaching insertion, not decurrent, dorsal and apical lamina unistratose; costa lacking or vestigial, composed of narrow cells, reaching to half the length of vaginant lamina, lacking in lower leaves (no cross sections seen); mid dorsal laminal cells plane, 32-67 $\times$ 15-30 $\mu \mathrm{m}$; mid vaginant laminal cells large, plane, 51.5-54.0 × 18.5-25.5 $\mu \mathrm{m}$. Gemmae, some leaves produce rhizoids from apical part (Fig. 2 D).

Fertile parts. Perigonia terminal on small, ca $1.5 \mathrm{~mm}$ long, stems; antheridia 230-250 $\mu \mathrm{m}$ long; perichaetia terminal, perichaetial leaves \pm $1.3 \mathrm{~mm}$ long; archegonia not seen; calyptra not seen. Sporophyte, seta $\pm 4 \mathrm{~mm}$ long, smooth, 1 per perichaetium; capsule symmetrical, 0.5-0.7 $\times 0.25-0.40 \mathrm{~mm}, \pm 32$ columns of quadrate-oblong exothecial cells; peristome scariosus-type, tooth base $\pm 33.5-43.0 \mu \mathrm{m}$ wide; operculum and spores not seen.

Fissidens enervis is a rare species known from a few small collections. It is characterized by its cuspidate leaf apex, $( \pm)$ ecostate leaves and large laminal cells. Rhizoids (hyaline, green or brown) growing from laminal cells are frequently present (seen in the type specimen as well as in Indian specimens). It strongly resembles $F$. hyalinus (not known from Africa). These two species may eventually prove to be conspecific. In this paper I take a conservative stand and consider specimens with unistratose limbidia and acute to acute-acuminate leaf apices to be $F$. hyalinus, and specimens with 1-2-stratose limbidia and cuspidate apices to be F. enervis. In Africa Fissidens enervis has been confused with $F$. dealbatus (see under this species). Sporophytic specimens are clearly distinct. Fissidens enervis has a smaller number of columns of exothecial cells (32 versus 40 or more in F. dealbatus). Gametophytic stems differ in the shape of the leaf apex (cuspidate in F. enervis and acute to acute-acuminate in $F$. dealbatus) and in having thinner limbidia (limbidia of $F$. dealbatus are 1-7-stratose). Rhizoids growing from laminal cells are present in all known collections of $F$. enervis but have not been observed in $F$. dealbatus. Unfortunately, capsules are frequently lacking and the collections are often too small to make trans-sections. In such cases the thickness of the limbidium is estimated from a surface view, which is unreliable.

REMARKs. The lectotype of $F$. enervis consists of a few poor stems, including one sporophyte with \pm 32 columns of exothecial cells on the theca.

Fissidens splachnoides Broth. is very similar. Its type (Queensland, Indooroopilly, F.M. Bailey 256 , p.p. (H-BR) also has a cuspidate leaf apex (Stone 1986, fig. 2) and 1-2-stratose limbidia. However, in this species the walls of the lateral bands of the vestigial costae are thickened [observed in the type specimen Bailey 256 (S!), in Norkett 16173 (BM!) and in New South Wales, Watts 5624 (H-Broth!)], which is not the case in an Indian specimen of $F$. enervis.

SUBSTRATE \& HABIT. On soil, growing scattered among other mosses.

Elevation. South Africa: $900 \mathrm{~m}$ a.s.l.; India: 900-1200 m a.s.l. (Bruggeman-Nannenga et al. 2016).

Distribution (amended). Southern Africa (South Africa), Russia? (Ignatov et al. 2007), India (Western Ghats). Rare.

To the extent that it could be checked, the African distribution of $F$. enervis in O'Shea (2006) refers, with the exception of the type specimen, to $F$. dealbatus. The $F$. hyalinus with 1-2-stratose limbidia and cuspidate apices in Ignatov et al. (2007) seems to refer to $F$. enervis.

SPECIMENS EXAMINED. SOUTH AFRICA, LeCTOTYPE (PRE); Natal, Nottingham Road, 900 m, IV 191, Van de Bijl (Sim 8648) (PRE). - INDIA, Kerala, Palakkad District, Nelliyampathi; on land cuttings, $1200 \mathrm{~m}$, 13.07.2015, K.M. Manjula 1138B (CALI, L).

ILluSTRATIONS. Bruggeman-Nannenga et al. (2016: figs 1 \& 2), Magill [1981: fig. 8(1-7)], Sim (1926: 18.900). 


\section{Fissidens metzgeria (Müll. Hal.) Broth.}

Fig. 3

Oefvers. Förh. Finska Vetensk.- Soc. 35: 38, 1893 Conomitrium metzgeria Müll. Hal., Linnaea 39: 358, 1875 - Protologue: [border area of DEMOCRATIC REPUBLIC OF THE CONGO and CENTRAL AFRICAN REPUBLIC], Monbuttu-regiones, prope Bongua inter Plagiothecium monbuttoviae, ut ex Diatomaceis elucet, in locis aquosis, 14. Aprili 1870. SchweinfurthLECTOTYPE (designated by Bruggeman-Nannenga 1997) with label: Monbuttu Land, inter Plagiothecium monbuttoviae vereinzelt, 14 IV 1870 . Collector not indicated (NY!); ISOLECTOTYPE: BM (slide 3619).

Fissidens bryum Müll. Hal. ex Dusén, Kongl. Svenska Vetensk. Acad. Handl. n.s. 28(2): 14, figs.: a, b \& tab. II, f. 8.1895 - Protologue: CAMEROON [Camerunia], supra Bomanam pagum, c. 1100 m, VII 1892, Dusén s.n. - Holotype label: Africa Occ., Camerunia in monte Camerun, ca. 1100 m, VII 1892, Dusén s.n. (S!); ISOTYPE label: Kamerun, Bomana, 1100 m, auf Steinen, VII 1892, Dusén 834 (PC-PV!).

Fissidens bryum Müll. Hal. ex Dusén var. terrestris P. de la Varde, Rev. Bryol. n.s. 4: 57, 1931 - Protologue: GABON, Tsengué (Monzo), sur terre argileuse, Le Testu 4880 - Holotype label: as protologue with added collection date: 6 I 1931 (PC-PV!).

Stem without or with weak central strand, not heterocaulous, with pinnately arranged leaves, unbranched, 5.0-21.0 × 1.5-5.0 mm, browning in $\mathrm{KOH}$ or not; rhizoids basal and from cortex of basal part of stem, brown, smooth; axillary cells not differentiated; leaves shiny, distant to close, up to 15 pairs, slightly crispate when dry, flattening when moistened, elliptical to elliptico-lanceolate with acute to acute-acuminate apex, 1.5-4.0 $\times$ $0.3-0.7 \mathrm{~mm}, 3.0-5.5$ times as long as wide, margin entire to undulate-entire, limbate; limbidium on all laminae of all leaves, ill-defined, lax, \pm reaching apices of leaf and vaginant lamina, reaching insertions of vaginant and dorsal laminae, in mid dorsal lamina 10.5-33.5 $\mu \mathrm{m}$ wide, unistratose, marginal; on vaginant laminae weak, up to $56 \mu \mathrm{m}$ wide, unistratose, marginal to weakly intramarginal; vaginant lamina $1 / 2(-3 / 5)$ of total leaf length, about half as wide as stem at insertion, slightly open, unistratose; dorsal lamina tapering towards base, straight, reaching insertion, not to inconspicuously decurrent; dorsal and apical lamina unistratose, infrequently with scattered, unicellular bistratose dots; costa lacking, rarely weakly developed; mid dorsal laminal cells oblong-hexagonal, $55.0-120.0 \times 15.0-53.5 \mu \mathrm{m}$, plane to inconspicuously convex, smooth; limbidial cells in mid dorsal lamina $130-150 \times 5-12 \mu \mathrm{m}$ with slightly thicker walls than inner cells; mid vaginant laminal cells oblong-rectangular 75-152 × 5-24 $\mu \mathrm{m}$. Clusters of gemmae frequently present on lamina, particularly near apex, less often growing from stem cortex; gemmae brown, unbranched to heavily branched, multi-cellular.

Fertile plants rare, perigonial and perichaetial stems hardly differ from vegetative ones, easily overlooked. Perigonia, perichaetia and synoicia terminal; perigonial plants up to $6 \mathrm{~mm}$ long, antheridia 210-500 $\mu \mathrm{m}$ long; perichaetia terminal, perichaetial leaves hardly longer than stem leaves, 1.5-4.0 mm long, archegonia 200-450 $\mu \mathrm{m}$ long; calyptra tightly clasping operculum, $0.65-0.70 \mathrm{~mm}$ long, smooth to scabrose. Sporophytes (only 2 very young ones seen), 2 per perichaetium.

Fissidens metzgeria is characterized by its ecostate, limbate leaves, ill-defined limbidia, 5-12 $\mu \mathrm{m}$ wide limbidial cells and large inflated cells $(55.0-120.0 \times 15.0-53.5 \mu \mathrm{m}$ in mid dorsal lamina). Epiphyllous clusters of multicellular gemmae are frequently present on the apical part of the leaf. The other two African ecostate, limbate species, F. dealbatus and F. enervis, have distinct, narrower limbidia of narrow limbidial cells and lack epiphyllous clusters of gemmae. Fissidens ecuadorensis Pursell \& Brugg.-Nann. is a smaller (stems up to $4 \mathrm{~mm}$ long) Neotropical ecostate species with a similar ill-defined limbidium.

SubSTRATE AND Habit. On soil, less often on rocks, living or dead wood. Often scattered among other mosses, rarely in mats or tufts.

HABITAT. On banks of paths, roads and streams in humid, shady to swampy sites and also near waterfalls. In all kinds of forest (montane and submontane rainforest, montane cloud forest, dry semi-deciduous forest, swamp forest, both pristine and secondary).

ElEvation. 360-2300 m a.s.l. 


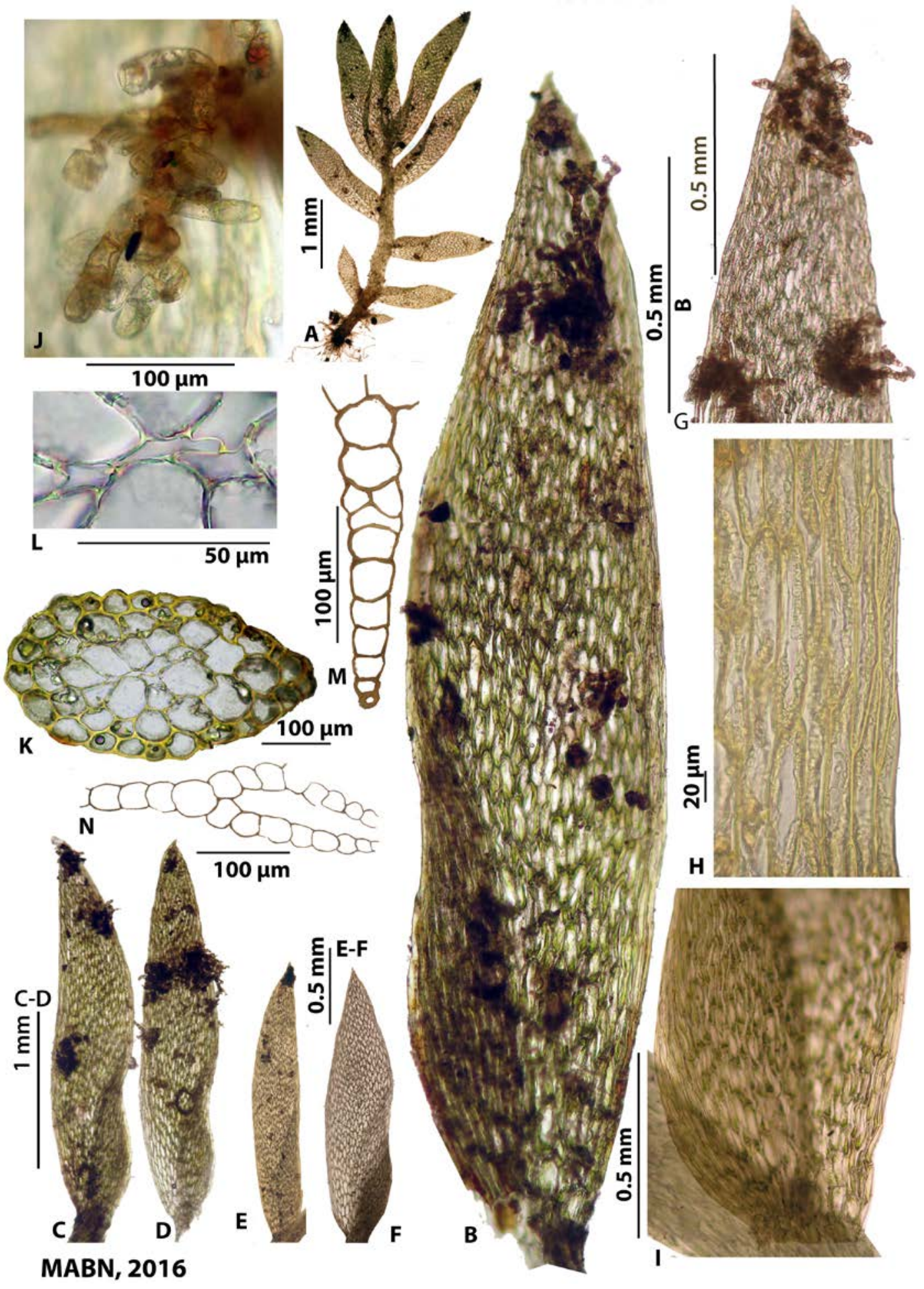


Distribution. Endemic to Africa. Known from west tropical Africa (Guinea; Schultze-Motel 1975, Nigeria), west central tropical Africa [Cameroon, Central African Republic, Democratic Republic of the Congo, Equatorial Guinea (Bioko), Gabon, São Tomé], northeast tropical Africa (Ethiopia; Hylander et al. 2017), east tropical Africa (Kenya, Rwanda, Tanzania, Uganda) and south tropical Africa (Angola; Müller 2015).

Selected specimens examined: CAMEROON, [British Cameroons], S. side Cameroon Mountain, Div. Victoria, Mann's Spring below Liwonge, (Brenan) Richards 4320 (PC-PV); Bamenda, Bafut-Ngemba Forest Reserve, Richards 5255 (PC-PV, BM). - CENTRAL AFRICAN REPUBLIC, Bangui, Assel 120 (PC, L). DEMOCRATIC REPUBLIC OF THE CONGO [Congo belgica], Mwenda, affluent de la Biangolo, Demaret 4741 (PC-PV); prov. Kivu, Irangi Forest Station $110 \mathrm{~km} \mathrm{~W} \mathrm{of}$ Bukavu, Bryotrop Exp. 1991, Pócs 6766 (EGR). - EQUATORIAL GUINEA, Insel Bioko, Berg Caldera $10 \mathrm{~km} \mathrm{~S}$ of Luba, $3^{\circ} 23^{\prime} \mathrm{N}, 8^{\circ} 32^{\prime} \mathrm{E}$, F. Müller B 104 (DR, L); Hochland von Moca, $3^{\circ} 20^{\prime} \mathrm{N}, 8^{\circ} 40^{\prime} \mathrm{E}$, F. Müller B 410, p.p. (DR, L). - GABON, entre Ipoungou et Dibandi (or Dibaudi?), Le Testu 6120 (PC-PV). - KENYA, North Kavirondo District, S.E. of road between Rondo and Kakamega Sawmills, Townsend 77/258, p.p. (E, L, a few mixed with $F$. intramarginatus s.1.). - NIGERIA, Prov. Benin, Distr. Benin, valley between Idanre and Olofin, Brenan \& Jones R3838 (E, L, p.p. mixed with F. zollingeri); S.E. State, Obudu, Cattle Range, McFarlane 5339A Mitt. (L, p.p. with $F$. porrectus). - RWANDA. Pref. de Cyangugu, Forêt de Nyungwe, Bryotrop Exp. 1991, Pócs 6473 (L);

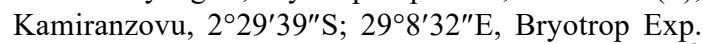
1991, Frahm 6330 (L, with F. porrectus). - SÃO TOMÉ AND PRÍNCIPE, SÃO TOMÉ, Picada para a Lagoa Amélia, Sérgio ST100 (L, LISU). - TANZANIA, SW from W Usambara Mts, on the plateau of Mafi Hill, near the headwaters of Kwalukonge stream, Pócs 8522/AN (EGR, L - one stem in with $F$. weirii); Mbulu Highlands, Guay Hill, Pócs 90096/AA, p.p. mixed with F. usambaricus (EGR, L). - UGANDA, Bushenyi District: Kasyoha-Kitomi FR, $0^{\circ} 19^{\prime} \mathrm{S}, 30^{\circ} 7^{\prime} \mathrm{E}$, Hodgetts U 4584A (E, L); Rukungiri District, Bwindi forest, Buhoma. $0^{\circ} 59^{\prime} \mathrm{S}$, $29^{\circ} 36^{\prime} \mathrm{E}$, Wigginton U8347 A (E, L).
ILlustrations: Potier de la Varde [1929: 3, and (same figure) 1936: 3; both as F. bryum]; BruggemanNannenga (2006a: fig. 7d-f).

\section{Fissidens usambaricus Broth.}

Fig. 3

Bot. Jahrb. Syst. 20: 182. 1894 - Protologue: TANZANIA, Usambara, Lutindi, am Boden in Hochwalde, spärlich, Holst 3472 , p.p. - HOLOTYPE: mica-slide without collection number H-BR!; ISOTYPES: BM!, S!.

Fissidens chevalieri Corb., Bull. Mus. Natl. Hist. Nat.18: 108. 1912 - Protologue: CENTRAL AFRICAN REPUBLIC, [Haut-Oubangui], Krébedjé (Fort-Sibut), 11 Oct. 1902, Auguste Chevalier s.n. - HOLOTYPE in Corbière's herbarium in PC (not seen); ISOTYPES: PC!, PC-PV! [both with label: Oubangui, Krébedjé, Chevalier 44A, 11-12 Oct. 1903 (orthographic error for 1902?)] and H-BR! (label: Oubangui, Krébedjé. Chevalier s.n. 11-12 X 1902!).

Fissidens usambaricus Broth. var. acutifolius P. de la Varde, Bull. Soc. Bot. France 73: 377, 29. $1926-$ Protologue: [CENTRAL AFRICAN REPUBLIC] près Ngono, $20 \mathrm{~km}$. N.-O. Bambari, R.P. Tisserant s.n. - HOLOTYPE label: Oubangui, $20 \mathrm{~km} \mathrm{~N} \mathrm{O} \mathrm{Bam-}$ bari, près Ngono, mêlé à Trichosteleum tisserantii sur tronc d'arbre mort. 1925, Tisserant s.n. (PV 2145B) (PC-PV!); ISOTYPE: près Ngono, 20 km N-O. Bambari, R.P. Tisserant (PV 2145B) (BM-000871903!).

Stem without or with weak central strand, not heterocaulous, mostly unbranched, 3.0-9.0(-15.0) $\times 1.5-3.0 \mathrm{~mm}$, with pinnately arranged leaves; rhizoids basal, infrequently from mid stem cortex, brown to hyaline; axillary cells not differentiated; leaves green, distant, 5-15 pairs, hardly altered to crispate when dry, broadly elliptical to broadly elliptico-oblanceolate or oblong with widely acute to obtuse or rounded-obtuse apex, 0.9-1.5(-2.1) $\times 0.4-0.6(-0.7) \mathrm{mm}, 2-3$ times as long as wide, elimbate, margin subentire, near apex sometimes serrulate; vaginant lamina $2 / 5-3 / 5$ of total leaf length, narrow, at insertion narrower than stem, slightly unequal, unistratose, infrequently with scattered unicellular bistratose dots; dorsal lamina

Fig. 3. Fissidens metzgeria (Müll. Hal.) Broth. A - stem, B-F - leaves (black areas are clusters of gemmae), G - leaf apex with 3 clusters of gemmae, $\mathrm{H}$ - limbidium mid dorsal lamina, I - insertion of leaf, $\mathrm{J}$ - cluster of gemmae, $\mathrm{K}$ - trans-section of stem, L - detail of $\mathrm{K}$ showing weak central strand, M \& N - trans-sections of leaf (M showing isolated bistratose dot in dorsal lamina). A from Pócs 90099/AA; B-D from Hodgetts U4254A; E, G-H, K-N from Müller B104; F, J from Müller B410; I from O'Shea U 5532A. 
\pm straight towards insertion, reaching insertion, occasionally decurrent, unistratose, rarely bistratose near insertion; apical lamina unistratose; costa \pm absent; mid dorsal laminal cells hexagonal, variable in size (see remark below), 22.5-93.0 $\times$ $14.0-40.0 \mu \mathrm{m}$, smooth, plane to inconspicuously convex; marginal cells smaller, isodiametric to oblong, on the mid dorsal lamina 15.0-33.5 $\times$ 6.5-15.9 $\mu \mathrm{m}$; mid vaginant laminal cells hardly differentiated to larger, 45.0-136.0 × 7.5-32.0 $\mu \mathrm{m}$; basal vaginant laminal cells hardly differentiated to oblong, $45.0-60.0 \times 7.5-14.5 \mu \mathrm{m}$. No gemmae seen.

Fertile parts. Gametangia (perigonia, perichaetia and synoicia) terminal; perigonial stems 0.5-2.3 mm long; antheridia 180-230 $\mu \mathrm{m}$ tall; perichaetial and synoicial stems $3-5 \mathrm{~mm}$ tall; archegonia $\pm 300 \mu \mathrm{m}$ long; perichaetial leaves 1.85-2.20 mm long; calyptra tightly covering rostrum, smooth to slightly bulging. Sporophytes rare. Seta $1.5-3.0 \mathrm{~mm}$ long, 1-2(-3) per perichaetium, smooth or slightly scabrose in basal half; capsule symmetrical, rarely slightly inclined, $0.40-0.65 \times$ $0.20-0.45 \mathrm{~mm}$, with \pm 32 columns of oblong to quadrate exothecial cells with thickened corners; peristome scariosus-type, tooth base $45-48 \mu \mathrm{m}$ wide; operculum rostrate, $0.55 \mathrm{~mm}$ long; spores subglobose, $8.0-13.0 \mu \mathrm{m}$ diam., thick-walled or not, smooth to indistinctly papillose.

This species is easily recognized by its elimbate, $( \pm)$ ecostate leaves and large laminal cells with a border of 1-2 rows of smaller, isodiametric to oblong cells. The variation of cell size in this species is remarkable. Some collections have relatively small, $22.5-45.0 \times 14.0-21.0 \mu \mathrm{m}$, mid dorsal laminal cells, whereas others have much larger, 56-80 × 30-40 $\mu \mathrm{m}$, mid dorsal laminal cells (e.g., $O$ 'Shea $2628 \mathrm{~A}$ and Müller $Z$ 215); mid vaginant laminal cells can be $45-60 \times 7.5-14.5 \mu \mathrm{m}$ in some collections or as large as $88-136 \times 17.5-32 \mu \mathrm{m}$ in others. The presence of transitional forms makes it impossible to distinguish distinct groups based on this character. Fissidens usambaricus is the only elimbate, ecostate species known from Africa. The ecostate $F$. hylogenes Dixon from New Zealand similarly has elimbate leaves but has smaller, \pm 12 $\times 9 \mu \mathrm{m}$ (versus 15.0-24.0 × 7.5-15.0 $\mu \mathrm{m}$ ) marginal cells and crenulate instead of subentire margins. [Specimen seen: Sainsbury et al., Musci exsicc. Novae-Zelandiae 10 (S)].

Substrate AND Habit. Mostly on soil, less often on rock, termite mounds or wood. Growing scattered among other mosses, rarely in loose or dense mats or tufts. Easily overlooked.

HABITAT. Usually collected on shady banks and road cuts, also found near a waterfall, on rock in streamlet and bank of stream. Known from dry semi-deciduous forests, mesic montane forests and rainforest (lowland, submontane and montane), also from an Afro-montane forest, woodbush, and from Pinus plantations. Many labels give no details.

\section{Elevation. 25-2400 $\mathrm{m}$ a.s.1.}

Distribution. A widespread African endemic. Known from Macaronesia: Cape Verde Islands (O'Shea 2006), west tropical Africa (Ivory Coast; O'Shea 2006), Nigeria (O'Shea 2006), west central tropical Africa (Cameroon; O'Shea 2006), Central African Republic, Democratic Republic of the Congo, Gabon, Rwanda, São Tomé (Shevock et al. 2013), northeast tropical Africa (Ethiopia), east tropical Africa (Kenya; O'Shea 2006), Tanzania, Uganda, south tropical Africa (Malawi) and southern Africa (South Africa, Swaziland; O'Shea 2006). New for Malawi and Gabon.

SElECTED SPECIMENS EXAMINED: CENTRAL AFRICAN REPUBLIC, types of Fissidens chevalieri. DEMOCRATIC REPUBLIC OF THE CONGO, prov. Kivu: Ruwenzori, Lanuri, Bequaert 4447 (PC, PC-PV, BM); Kahuzi-Biega Nat. Park. Surroundings of Camp Biega $30 \mathrm{~km} \mathrm{~W}$ of Bukavu. Loc. 128, Bryotrop Exp. 1991, Pócs 7356, p.p., 1 stem (L); Pinga, 96 km NW

Fig. 4. Fissidens usambaricus Broth. A \& B - sporophytic plants, C - mid leaf of perichaetial stem, D \& E - leaf apices, $\mathrm{F}$ - margin mid dorsal lamina (marginal cells at right), $\mathrm{G}$ - insertion of leaf, $\mathrm{H}$ - part of seta showing large cortical cells, I - capsule with calyptra. A from Pócs 90096/AA; B, C from Porley U45A; D, H from Hylander 4527; E, G from Porley 410A; F from Porley U636A; I from Lübenau SA309. 

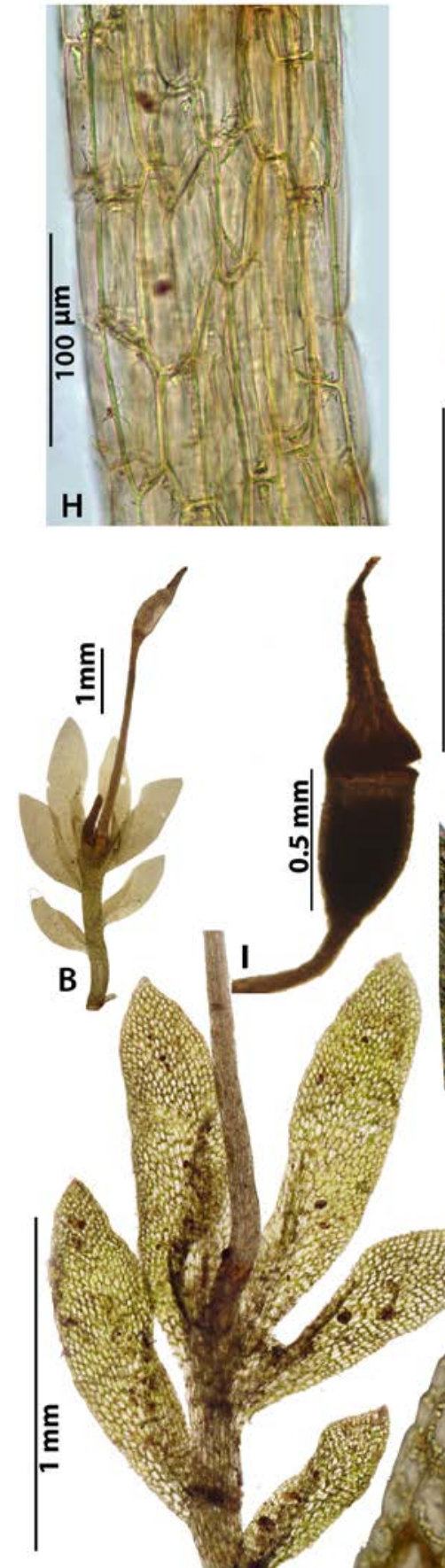

A

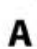

MABN, 2016

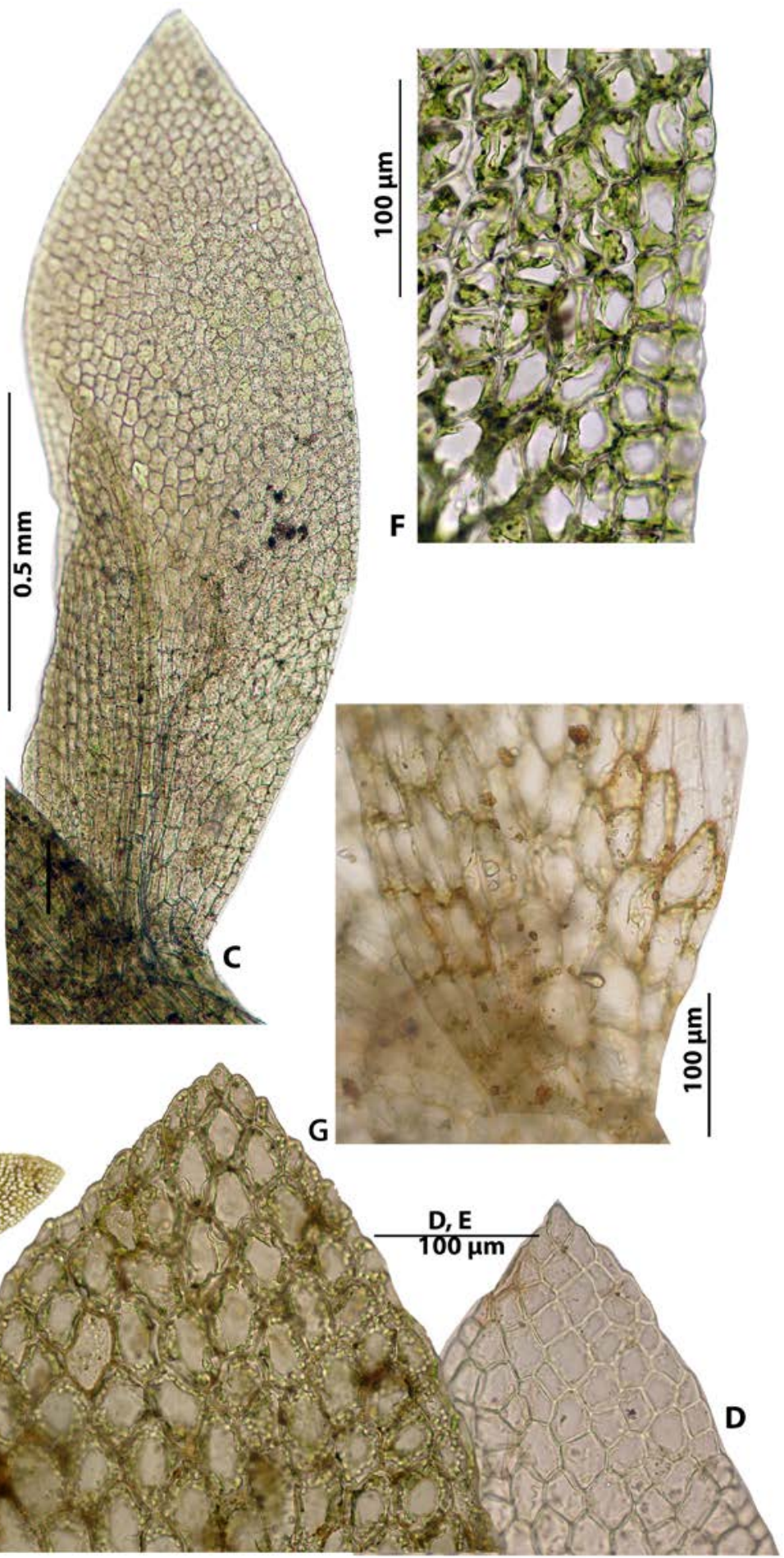


Goma, Flusstal 4 km NNO Ort; $1^{\circ} 0^{\prime} \mathrm{S}$. Br; $28^{\circ} 43^{\prime} \mathrm{O}$. L., F. Müller Z 215 (DR, L). - ETHIOPIA, Kaffa, Gimbo, Bonga. $1.5 \mathrm{~km}$ SE of Central Bonga, Hylander 4527 (S, L); Kaffa, Gimbo, Ufudo, Chechuwuta forest, $6 \mathrm{~km} \mathrm{~S}$ of Gimbo, Hylander 4532 (S, L). - GABON, Ogooué-Ivindo, Makokou, Réserve Intégrale d'Ipassa, $0^{\circ} 30^{\prime} 43.0^{\prime \prime} \mathrm{N} 12^{\circ} 48^{\prime} 12.1^{\prime \prime} \mathrm{E}$, Vanderpoorten GAB 1399 [a single stem mixed with $F$. glaucissimus (L)]. - MALAWI, S. Escarpment of Zomba Plateau on the S slope of Kuchawe summit, Pócs 9171/BB (EGR, L mixed with a few $F$. dealbatus and $F$. rotereaui). - SOUTH AFRICA, Mariepskop, Vorster 1449B (L); Transvaal, Drakenberge, Lübenau SA309 (L). - RWANDA, Rwanda. Pref. de Cyangugu, Forêt de Nyungwe, Uwinka Station along road from Butare to Cyangugu, Bryotrop Exp. 1991, Frahm 6494 (BONN, L). - TANZANIA, Mbulu Highlands, Quay Hill at the NNE end of Nou Forest Reserve, $6 \mathrm{~km} \mathrm{SSW}$ of Mbulu town, Pócs 90096/AA, p.p. mixed with F. metzgeria (EGR, L); Mbeya District, Forest Reserve by the Mbeya/Chunya road $c a 12 \mathrm{~km}$ from Mbeya. Townsend 75/330 (E, p.p., with F. dealbatus). - UGANDA, Kabale District, Bwindi National Park, Ruhija, Porley U45a, p.p., mixed with F. intramarginatus s.l. (E, L); Kabarole, Rwenzori National Park, lower Mubuku River; $0^{\circ} 21^{\prime} \mathrm{N}, 30^{\circ} 1^{\prime} \mathrm{E}$, Hodgetts $U$ $4534 A$, p.p. mixed with $F$. dealbatus (E, L); Rukungiri Distr., Bwindi NP, Porley U $636 A$ c. sp. (E, L).

IlluSTRATIONS: Bruggeman-Nannenga (2006a: fig. 7 g-i), Chuah Petiot (2003: fig. 35), Magill (1981: fig. 8-13), Salmon (1899: fig. 16).

\section{COSTATE SPECIES}

All species included in the present paper have large (at least $30 \mu \mathrm{m}$ long) laminal cells, limbidia on all laminae of all or most leaves, and a subgenus Aloma sporophyte. Costae are frequently short for the genus (e.g., F. flaccidus, F. grandifolius) but can be excurrent, as in F. minutifolius Broth. \& $\mathrm{P}$ de la Varde and F. zollingeri Mont. Worldwide, costate species with large cells include limbate, partly limbate and \pm elimbate species. Most have smooth cells but a few have mammillose cells (e.g., F. flaccidus var. mammillosus Brugg.-Nann., F. lindbergii A. Jaeg., F. yucatanensis Steere, $F$. biformis Mitt.). In F. zollingeri (smooth cells) and F. biformis Mitt. (with mammillose cells, not included in this paper), large inflated cells are restricted to the vaginant laminae.

\section{Fissidens flaccidus Mitt.}

Fig. 5

Trans. Linn. Soc. London 23: 56, t. 6, f. 18, 1-4. $1860-$ Protologue: NIGER, on the earth, Vogel - HolotyPe NY!; ISOTYPES BM as Vogel 2!, Vogel 3! and Vogel 4 !

Fissidens atroviridis Besch., Ann. Sci. Nat. Bot. sér. 7 , 2: 86. 1885 - Protologue: MAYOTTE, sur la terre à M'Sapéré, M. Marie 10 - HOLOTYPE: BM, ISOTYPES PC! (as Mt. Sapéré, 19 II 1881), NY! (sine dato), H-BR! (as Comore-insula, Mayotte, Marie s.n., sine dato).

Fissidens cellulosus Mitt., J. Linn. Soc. Bot. 22: 319. 1886 - Protologue/label: [TANZANIA], Usagara Mountains, on the earth. Bishop Hannington; HOLOTYPE: NY!, ISOTYPE: H!

Fissidens luridus Renauld \& Cardot, Bull. Soc. Roy. Bot. Belgique 29: 172. 1890 - Protologue: MADAGASCAR, Imerina, Mahamasina, alt. 1210 m (Camboué) - LeCtotype (designated by Bruggeman-Nannenga 2009) labelled: Madagascar, Mahamasina, Ouest de Imerina, alt. 1210 m, Camboué s.n (PC! stamped herb. Cardot). The specimen with the same label in Renauld's herbarium (PC) is F. leucocinctus Hampe.

Fissidens bocarangensis P. de la Varde, Rev. Bryol. Lichénol. 11: 166. 1939; new name for $F$. ensifolius P. de la Varde, Rev. Bryol. 9: 195, f. 1. 1937 (hom. illeg., non F. ensifolius Broth.) - Protologue: CENTRAL AFRICAN REPUBLIC [Oubangui], Bocaranga, sur l'humus, Eckendorff s.n. - HOLOTYPE: PC-PV! (labeled: Oubangui, Bocaranga, 31 VII 1934, Eckendorff s.n. (PV 5971).

Non-African synonyms:

Fissidens maceratus Mitt., Trans. \& Proc. Roy. Soc. Victoria 19: 91. 1882 - Protologue: AUSTRALIA, Queensland, Brisbane River, Bailey - HoLOTYPE: NY.

Fig. 5. Fissidens flaccidus Mitt. var. flaccidus. A - vegetative stem, B \& C - perichaetial stems, D-F - leaves, G-H - leaf apices, I - mid dorsal lamina, $\mathrm{J}$ - insertion of leaf, $\mathrm{K}$ - trans-section of leaf showing bryoides-type costa, $\mathrm{L}$ - clusters of axillary gemmae, $\mathrm{M}-2$ gemmae. - F. flaccidus var. mammillosus Brugg.-Nann., var. nov. $\mathrm{N}$ - mammillae in side view, $\mathrm{O}-$ mid dorsal laminal cells. A from Pócs 9168/O; B from Pócs 9168/Q; C, H from type F. ensifolius; D, M from Pobeguin 306; E, K from Müller E194; F from Dorr 2752; G, I, from Pócs 9168/P; J from MacFarlane 811; L from McFarlane 168; N, O from type specimen of F. flaccidus var. mammillosus. 


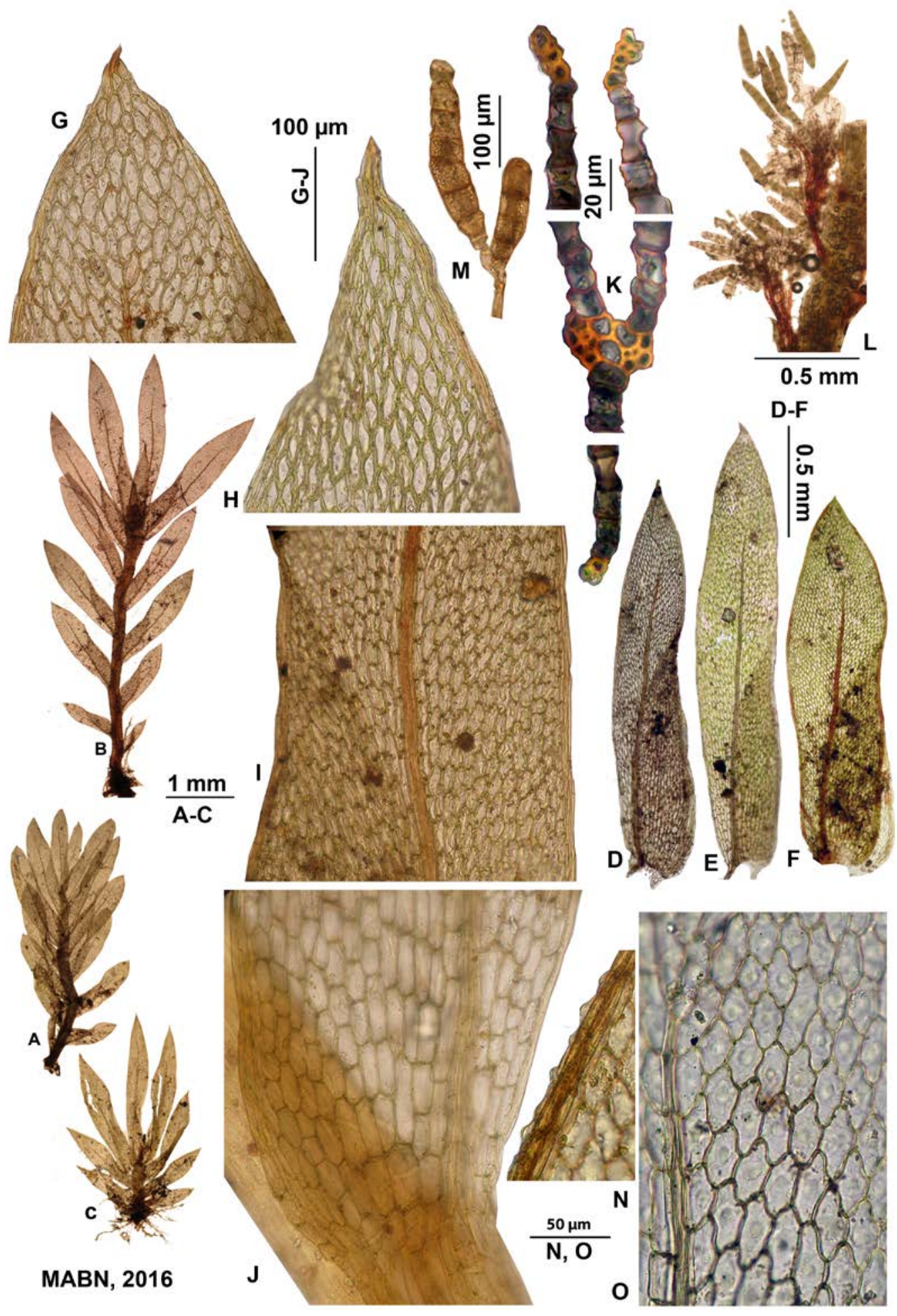


Fissidens splachnobryoides Broth. in K. Schum. \& Lauterb., Fl. Schutzgeb. Südsee: 81. 1900 - ProTOLOGUE: NEW GUINEA, Butaueng, Kaernbach (HOLOTYPE: H-BR).

REMARK. O'Shea (2006) incorrectly listed F. minutus var. minutus Thwaites \& Mitt. in Mitt. (=F. pallidinervis Mitt.) as synonym of $F$. flaccidus.

\section{5a. F. flaccidus var. flaccidus}

Fig. 5A-M

Stems without or with weak central strand, browning in $\mathrm{KOH}$, hardly heterocaulous, mostly unbranched; vegetative stems $1.4-13.0 \times 0.7-$ $4.0 \mathrm{~mm}$ (sporophytic/perichaetial stems 5-10 $\times$ 2-3 mm); rhizoids basal and from stem cortex, pale to dark brown, smooth; axillary nodules not differentiated; leaves pinnately, less often frondosely arranged, distant, less often close, 5-15(-32) pairs, strongly crispate to hardly altered when dry, usually flattening in $5 \% \mathrm{KOH}$, elliptical, ellipticolanceolate and elliptico-oblanceolate with acute to acute-acuminate apex ending in pointed colored cell, (0.6-)0.8-2.8 × 0.10-0.70 mm, 3.5-7 times as long as wide; limbidium on all laminae of all well-developed leaves, reaching leaf apex, often becoming weak towards leaf apex (Fig. 5G), occasionally confluent into ecostate mucro (Fig. $5 \mathrm{H}$ ), confluent at apex of vaginant laminae, mostly reaching insertion of dorsal lamina, on vaginant lamina often becoming lax and indistinct proximally and reaching insertion or not, on mid dorsal laminae 8-21(-27) $\mu \mathrm{m}$ wide, 1-2-stratose, marginal; on mid vaginant lamina (11.0-) 14.5-27.0 $(-50.0) \mu \mathrm{m}, 1-2$-stratose, near insertion marginal or weakly intramarginal; vaginant lamina $1 / 2-3 / 5$ of leaf length, at base less wide than stem, frequently slightly decurrent (best visible with $\mathrm{KOH}$; Fig. 5J), unistratose, \pm closed; dorsal lamina narrow, straight to slightly rounded at insertion, reaching insertion, not decurrent; dorsal and apical lamina unistratose; costa ending 7-21 cells below leaf apex, in cross section of bryoides-type; mid dorsal laminal cells (18.5-)23.0-50.0(-65.0) $\times 8.0-25.5(-28.0) \mu \mathrm{m}$, smooth, plane to lowly convex; mid vaginant laminal cells oblong, 26.5-76.5(-80.0) × 7.0-24.0(-30.0) $\mu \mathrm{m} ;$ juxtacostal cells of vaginant lamina 44.0-58.0(-72.0) $\times 9.5-18.0 \mu \mathrm{m}$; axillary fascicles of short rhizoids bearing multicellular, uniseriate, hyaline to brown gemmae (Fig. 5L \& M) often present.

Fertile parts, perigonia and perichaetia on separate plants, perigonial plants $2-3 \mathrm{~mm}$ long, hardly differentiated and easily overlooked, perigonia terminal, antheridia $\pm 250 \mu \mathrm{m}$ long; perichaetia terminal on plants or, less often, on branches; perichaetial leaves longer than stem leaves (1.3-)1.7-3.0 mm long; archegonia 200$380 \mu \mathrm{m}$ long; calyptra not seen. Sporophyte, seta 2-5 mm long, smooth, 1 per perichaetium; capsule erect, $0.50-0.65 \times 0.35-0.45 \mathrm{~mm}$ with $\mathrm{ca} 32$ columns of quadratic-oblong, exothecial cells with thickened corners; peristome scariosus-type (only basal part seen), tooth base 54.5-56.5 $\mu \mathrm{m}$ wide; operculum long-rostrate, $0.5 \mathrm{~mm}$ long; spores 12.5-18.0 $\mu \mathrm{m}$ diam., finely papillose.

Fissidens flaccidus var. flaccidus is characterized by its completely limbate leaves, (1-)2-stratose limbidia, smooth, large cells (in mid dorsal lamina, at least some $30 \mu \mathrm{m}$ or more long), short costae ending 7-21 cells below the leaf apex, and (0.6-)0.8-2.8 mm long leaves. Multicellular gemmae on short, axillary rhizoids are often present. Archegonia are frequently present but sporophytes are rare. Variability. Typically the laminae are unistratose and the limbidia 1-2-stratose. Müller E 201 is a robust expression in which all laminae have unicellular bistratose dots and the limbidia are 2(-3)-stratose near the insertion of vaginant laminae. Fissidens flaccidus var. flaccidus is most likely to be confused with $F$. grandifolius, which differs by having inclined capsules, 1-4 setae per perichaetium, axillary perigonial buds and dwarf male plants at the base of perichaetial stems (terminal in $F$. flaccidus). The few sporophytic plants of $F$. flaccidus observed [type-specimen of $F$. bocarangensis; Stone (1988) as F. maceratus; Eddy (1988) as $F$. atroviridis] have 1 seta per perichaetium and erect capsules. Whereas sporophytic collections of the two species are easily distinguished, this is not true for vegetative collections. However, though both species have 1-2-stratose limbidia (in one and the same leaf), limbidia of F. flaccidus are essentially bistratose, whereas those of $F$. grandifolius 
are more often unistratose. Furthermore, though their cell sizes overlap, cells of $F$. grandifolius are typically somewhat larger (mid dorsal laminal cells $(28.0-) 34.5-71.0(-77.0) \times 12.5-37.0 \mu \mathrm{m}$ versus $(18.5-) 23.0-50.0(-65.0) \times 8.0-25.5(-28.0) \mu \mathrm{m}$ in $F$. flaccidus); moreover, gemmae are common in F. flaccidus but have not been observed in F. grandifolius. The Namibian F. capriviensis Magill (not seen) is corticolous, has weaker limbidia and is smaller in all respects (Magill, 1981). The minute $F$. minutifolius has longer costae which reach the leaf apex. The South African species F. wageri Dixon and F. splachnifolius Hornsch. similarly have large cells and short costae, but are easily distinguished by their elimbate leaves (Magill 1981). Outside Africa, F. flaccidus resembles the Neotropical $F$. dissitifolius Sull. that differs by having shorter limbidia which end below the leaf apex and having smaller laminal cells [(13.9-)18.029.0(-36.0) × 9.0-16.0(-22.0) $\mu \mathrm{m}$; Pursell 2007].

FISSIDENS FLACCIDUS, F. MOLLIS AND F. MACERATUS. Fissidens mollis, a species from the Neotropics, was considered conspecific with F. flaccidus by Bruggeman-Nannenga and Pursell (1995). During the present study it appeared that the African specimens, including the type specimen of F. flaccidus, differ essentially from Pursell's (2007) diagnosis by having thinner limbidia [(1-)2-stratose rather than 2-4-stratose] and shorter leaves (up to $2.8 \mathrm{~mm}$ versus up to $5.0 \mathrm{~mm}$ long). Moreover, whereas in the Neotropics the costae vary between ending as many as 18 cells below the leaf apex to percurrent (Pursell 2007), the costae of African collections always end well below the apex. Neotropical specimens agreeing with Pursell's diagnosis (long leaves and thick limbidia confluent at the apex) include the type specimen of $F$. mollis. Therefore this species is here reinstated. Both species have limbate leaves and large cells, and frequently have axillary, multicellular gemmae. Fissidens flaccidus s.str. is also known from the Neotropics (for an example see examined specimens). Its distribution in the Neotropics is unknown. Fissidens maceratus Mitt. was correctly subsumed under F. flaccidus (Pursell 1997).

Substrate AND HABIT. On rock (unspecified, limestone, travertine, walls) and soil. Once collected on a termite mound. Growing in mats, tufts or scattered, often sparsely intermixed with other species and then easily overlooked.

HABITAT. mostly in forests [lowland rainforest $(7 \times)$, riverine forest $(6 \times)$, also in moist semi-deciduous rainforest, submontane rainforest, evergreen forest, mixed low-elevation hardwood forest, secondary low-elevation tropical hardwood forest with palms, and degraded, dry forest], also collected in Sudano-Guinean savanna, plantations and gardens. Frequently growing near water [stream banks, near waterfalls, irrigated limestone (travertine bank), man-made walls of ditches, swimming pools, etc.], occasionally submerged.

Elevation. 0-1800 m a.s.1. (based on African collections).

Distribution. Widespread and common in Africa. Macaronesia (Cape Verde Islands); west tropical Africa (Ghana, Guinea, Ivory Coast, Niger, Nigeria, São Tomé, Sierra Leone); west-central tropical Africa (Central African Republic); east tropical Africa (Tanzania, Uganda); south tropical Africa [Angola (Müller 2015), Zambia, Zimbabwe (O'Shea 2006)]; southern Africa (South Africa) and western Indian Ocean (Comoro islands, Madagascar, Mauritius, Réunion, Rodriguez, Seychelles, Socotra; O'Shea 2006). Outside Africa known from Brazil, Asia, Australia and Oceania. New for Guinea and South Africa.

SPECIMENS EXAMINED: CAPE VERDE ISLANDS, Brava, an der Strasse zum Flughafen, Lindlar 95 (BONN). - CENTRAL AFRICAN REPUBLIC, Bamingui-Bangoran, Parc de Manovo-Gounda-Saint Floris. Campement de Koumbala, $8^{\circ} 30^{\prime} \mathrm{N}, 21^{\circ} 13^{\prime} \mathrm{E}$, Prendergast 91 (PC, L); Bocaranga, sur la route Bocaranga-Kounnang près village Zölé, Eckendorffs.n. (L). COMOROS, Ndzuani (Anjouan) Island, NW coast near Ouani, near Hotel Guinguette, Pócs 9168/K, M, O, Q (all EGR, L); collapsed Crater of Mt Pamouni on the $\mathrm{S}$ end of the island, E of M'rijou village, $12^{\circ} 20^{\prime} 21^{\prime \prime} \mathrm{S}$, 4429'57"E, Pócs, Magill \& Rupf 9281/G (EGR, L); Ngazidja (Grande Comore) Island, Ikoni Town on the West Coast below the volcanic cliffs at the fort hill, Pócs 9148/B, p.p. a few stems (EGR, L). - GHANA, Ashanti Region, Bobiri Forest reserve; $6.41^{\circ} \mathrm{N} 1.20^{\circ} \mathrm{W}$, Jouko 040001-64 with F. ramulosus (H, L). - GUINEA, Djallon-Timbo, Pobeguin 306 a few stems (L). - IVORY 
COAST, Man, Cascade de Man $4 \mathrm{~km}$ W of Man; $7^{\circ} 25^{\prime} \mathrm{N}, 7^{\circ} 35^{\prime} \mathrm{W}$. F. Müller E 201 (L, DR); - MADAGASCAR, prov. Antananarivo, Antananarivo, Parc de Tsimbazaza, $18^{\circ} 55^{\prime} \mathrm{S}, 4^{\circ} 31^{\prime} \mathrm{E}$, L.J. Dorr 2752 (MO, $\mathrm{L}$ a few stems among $F$. androgynus); Mahamasina, ouest de Tanararive, Imerina, Camboué s.n. (PC). MAURITIUS, Cave near Bassin Anglais, Curepipe. Een M 443 (S, PC). - NIGER (type F. flaccidus (NY, BM). - NIGERIA, W-Nigeria, Ijebu Prov., Ijebu-Ode, between Emuren and Imagbon, McFarlane 168 (L); Lagos State, Epe, McFarlane 278 (L). - RÉUNION, Bras de Cilaos, route N5 vers Cilaos, entre Ilet Furcy et Le Petit Serré, Arts RÉU 10/16 (BR, L); la Côte aux Vents, Anse des Cascades $2 \mathrm{~km}$ NNE of Bois Blanc on $\mathrm{E}$ coast, $21^{\circ} 10^{\prime} \mathrm{S}, 55^{\circ} 50^{\prime} \mathrm{E}$, Bruggeman-Nannenga 11785 (L, REU). - SÃO TOME \& PRINCIPE, São Tome Island, $6 \mathrm{~km}$ above Guadalupe near the village of Baoesperança, Lat/Long NAD 83: $00^{\circ} 20^{\prime} 19.5^{\prime \prime} \mathrm{N}$, $06^{\circ} 37^{\prime} 36.5^{\prime \prime}$., Shevock et al. 50025 with F. ramulosus Mitt. (L); Island of Principe, at roça Belo Monte Resort, Lat/Long NAD 83: $01^{\circ} 41^{\prime} 07.2^{\prime \prime} \mathrm{N}, 07 .{ }^{\circ} 26^{\prime} 38.0^{\prime \prime} \mathrm{E}$., Shevock et al. 49760 (L). - SEYCHELLES, Mahé, La Poudrière Road, Norkett 16123 (BM, L); Path to le Niol road, Norkett 18657 (BM), Beau Vallon, Norkett 18677 (BM); Praslin, old track, Norkett 18385 (BM). - SIERRA LEONE, Kangari Hills, Masati dry path in thick jungle (serpentinic ground). 14 IV 1955. V. Marmo s.n. (H, L). - SOUTH AFRICA, Transvaal, Wolfspruit, Ofcolaco, Brenan BM 3280, p.p., a few among F. cf dealbatus (E, L 1 stem). - RODRIGUEZ, Rivière Cascade Victoire bei Port Sud-Est, F. Müller R743 (DR, L); Port Mathurin S, Cascade Pigeon, F. Müller R 751 (DR, L). - TANZANIA, S. Foothills of Mt Meru, $17 \mathrm{~km}$ E of Arusha, along Malala Stream, Pócs \& Van Zanten $86125 / G, H$, p.p. (EGR, L); E. Usambara Mts, Mtai Forest Reserve, Pócs \& Farkas 86246/H (EGR, L); Mts Chemka, Jones \& Pócs 6382/F, p.p. with F. zollingeri (EGR, PC); West Usambara Mts, above Mazinde village, Pócs 8436/AE, p.p. (EGR, L); Ulanga District, Mahenge Plateau, Mselezi Forest Reserve, Pócs, Minja \& Towo 87202/B (EGR, L); West slopes of Nguru Mts, between Magunga and Maskati villages, Kis \& Pócs 9103/A (EGR, L a few mixed with F. megalotis subsp. helictocaulos); Morogoro, on slopes behind University campus, Pócs $8663 / P$, p.p. (EGR, L mixed with other species); Southern Highlands, Mt Rungwe E of Rungwe village, Pócs 6777/A, AE, AF, AJ (PC, EGR, L). - UGANDA, Kabarole, Kibale Forest NP. Between Isunga and Dura River. $0^{\circ} 29^{\prime} \mathrm{N}, 30^{\circ} 21^{\prime} \mathrm{E}, J . W$. Bates U8630A, p.p., with F. dealbatus and F. zollingeri (E, L). - ZAMBIA, $13 \mathrm{~km}$ East of Lusaka, Pócs \& Kornás $6609 / G$, p.p. (EGR).
BRAZIL, Rio de Janeiro State, Rio de Janeiro, Quinta da Boa Vista, Vital 5847 (SP, L).

Selected illustrations: Bruggeman-Nannenga (2006a: fig. 8), Bruggeman-Nannenga \& Arts (2010: fig. 23), Eddy (1988: fig. 82, as F. atroviridis), Iwatsuki \& Suzuki (1982: pl. V, as F. splachnobryoides), Li (1985: fig. 2a-j, as F. splachnobryoides), Potier de la Varde (1937: fig. 1, as F. ensifolius); Stone (1888: figs $1 \& 2$, as F. maceratus; type specimens of $F$. maceratus and $F$. splachnobryoides).

5b. F. flaccidus var. mammillosus Brugg.-Nann., var. nov. Fig. $5 \mathrm{~N} \& \mathrm{O}$

TyPE: SIERRA LEONE, Kambui Hills, Bambano, disused chrome mine, on wall of culvert in deep shade, 11 VIII 1966, Harrington 588 (HOLOTYPE: BM, ISOTYPE: L).

Diagnosis. The new variety differs from var. flaccidus by its mammillose (low-conical with inconspicuously thickened apical area) laminal cells. The mammillae are best observed in leaf folds or in surface view. In cross section they are hard to observe. The new variety resembles the smaller F. lindbergii Mitt. from Central and northern South America. Stone (1988) described and figured a similar-looking Fissidens from Queensland without naming it, but the mammillae in her figure do not have a thickened apex.

SubSTRATE, HABIT AND HABITAT. In tuft on wall of culvert in deep shade; semiaquatic (covered by diatoms).

Distribution. African endemic. Sierra Leone, known from the type locality only.

6. Fissidens grandifolius Broth. \& P. de la Varde Fig. 6

in P. de la Varde, Bull. Soc. Bot. France 73: 57, f. 25,1. 1926 - Protologue: [GABON], sur terre argileuse. Rive gauche de la Ngounyé, entre Udendé et Labo, XII 1924, Le Testu 5346 - LeCtotype (nov.) with label: Rive gauche de la Ngounyé entre Udendé et Labo, en forêt, sur argile, 29 10-bri 1924, Le Testu 5346 (PV-PC!; ISOLECTOTYPE: H-BR).

Stem without or with weak central strand, mostly unbranched; vegetative stems, frondose to elongate-frondose, variable in size, $(1.5-) 2.5-5.0 \times$ 1.0-4.0 mm, unbranched; sporophytic stems taller, 
4-8 $\times 3-5 \mathrm{~mm}$, with frondosely to pinnately arranged leaves; rhizoids basal and from stem cortex, brown to hyaline, smooth; axillary nodules not developed; leaves close, less often distant, 4-9 pairs, shriveled and crispate when dry, not well flattening in water, flattening in 5\% KOH, elliptical, ellipticolanceolate to elliptico-oblanceolate with acute to acute-acuminate apex, ending in large pointed cell, limbate, in vegetative stems (1.0-) 1.6-3.2 $\times 0.3-$ $0.7 \mathrm{~mm}, 3.5-6.5(-7.5)$ times as long as wide; in sporophytic stems $3.3-3.9 \times 0.5-0.6 \mathrm{~mm}, 5.5-7.8$ times as long as wide; limbidium on all laminae of all well-developed leaves, confluent at leaf apex, often becoming weak towards leaf apex, confluent at apex of vaginant laminae, becoming weak towards insertion of vaginant lamina, reaching or \pm reaching insertion of dorsal lamina; in mid dorsal lamina 11-32 $\mu \mathrm{m}$ wide, $1(-2)$-stratose, marginal, on vaginant laminae (13-) 16-43 $\mu \mathrm{m}$ wide, 1(-2)-stratose, marginal to weakly intramarginal; vaginant lamina $1 / 2-3 / 5$ of leaf length, at base narrower than stem, closed to \pm closed, unistratose; dorsal lamina narrow, straight to slightly rounded at base, reaching insertion, not decurrent, dorsal and apical lamina unistratose; costa ending 10-26 cells below leaf apex, weak in upper part, in lower leaves not always exceeding length of vaginant laminae, in cross section bryoides-type; mid dorsal laminal cells hexagonal, large, variable (28.0-)34.5-71.0(-77.0) × 12.5-37.0 $\mu \mathrm{m}$, smooth, plane to inconspicuously convex; mid vaginant laminal cells (30.0-)40.0-110.0 × 10.0-32.0 $\mu \mathrm{m}$, smooth, plane; basal vaginant laminal cells oblong, 69.0-114.0 × 12.0-29.0 $\mu \mathrm{m}$; gemmae not observed.

Fertile parts, perigonia and perichaetia on same stem, perigonia frequent, terminal on axillary, stalked (Fig. 6 I, J), budlike, 0.3-0.7 mm long (including stalk) branches and on tiny plants at base of perichaetial plants; antheridia 150-180 $\mu \mathrm{m}$ long; perichaetia terminal, perichaetial leaves (1.8-)3.3-4.0 mm long, archegonia 150-300 $\mu \mathrm{m}$ long; calyptra $0.7 \mathrm{~mm}$ long, smooth. Sporophyte, seta 5-10 mm long, smooth, 1-4 per perichaetium; capsule oblique, small, $0.4-0.6 \times 0.2-0.35 \mathrm{~mm}$, with $c a 32$ columns of exothecial cells with strongly thickened corners; peristome scariosus-type, tooth base 50-54 $\mu \mathrm{m}$ wide; operculum $0.5 \mathrm{~mm}$ long (immature); spores subglobose, 9.0-14.5 $\mu \mathrm{m}$ long, faintly papillose.

Fissidens grandifolius is characterized by its limbate leaves, large cells, and 1-4 setae per perichaetium, inclined capsules, stalked axillary perigonial buds and dwarf male plants at the base of perichaetial stems. The limbidia are uni- to bistratose. There are typically \pm 32 columns of exothecial cells, but sometimes more, due to extra cell divisions on one side of the capsule. The species is highly variable in size and cell size. Sporophytic stems tend to be taller and have longer leaves than vegetative ones, and more often have pinnately arranged leaves. A small expression was identified by Shevock et al. (2013) as F. palmatus. Based on the available material it seemed impossible to demonstrate a sharp distinction between small and large expressions. Fissidens grandifolius can also be confused with $F$. flaccidus. For differences see under the latter.

FISSIDENS PALMATUS AND F. GRANDIFOLIUS. Both $F$. palmatus and the African $F$. grandifolius display two expressions. As indicated above, the African $F$. grandifolius has large and small expressions which are not sharply separated. Pursell's (2007) concept of Neotropical F. palmatus is broad and includes $F$. palmatus Hedw. s.str. with percurrent costae as well as expressions with costae that end well below the apex. The latter used to be known as F. reticulosus (Müll. Hal.) A. Jaeger in the Neotropics. Small non-sporophytic expressions of the African F. grandifolius resemble the $F$. reticulosus expression; indeed, one specimen was reported as F. palmatus by Shevock et al. (2013). The two species may prove to be conspecific in future but the situation is complex. It seems significant that $F$. palmatus s.str. is unknown from Africa, whereas the large expression of $F$. grandifolius is restricted to West Africa. In contrast to F. palmatus in the Neotropics, F. grandifolius has sporophytic plants that tend to be taller and to have longer leaves, (3.3-3.9 mm versus up to $2.8 \mathrm{~mm}$ long) and more setae (1-4 per perichaetium, versus 1-2). There may be differences in cell size as well, but this could not be established as it is not clear 


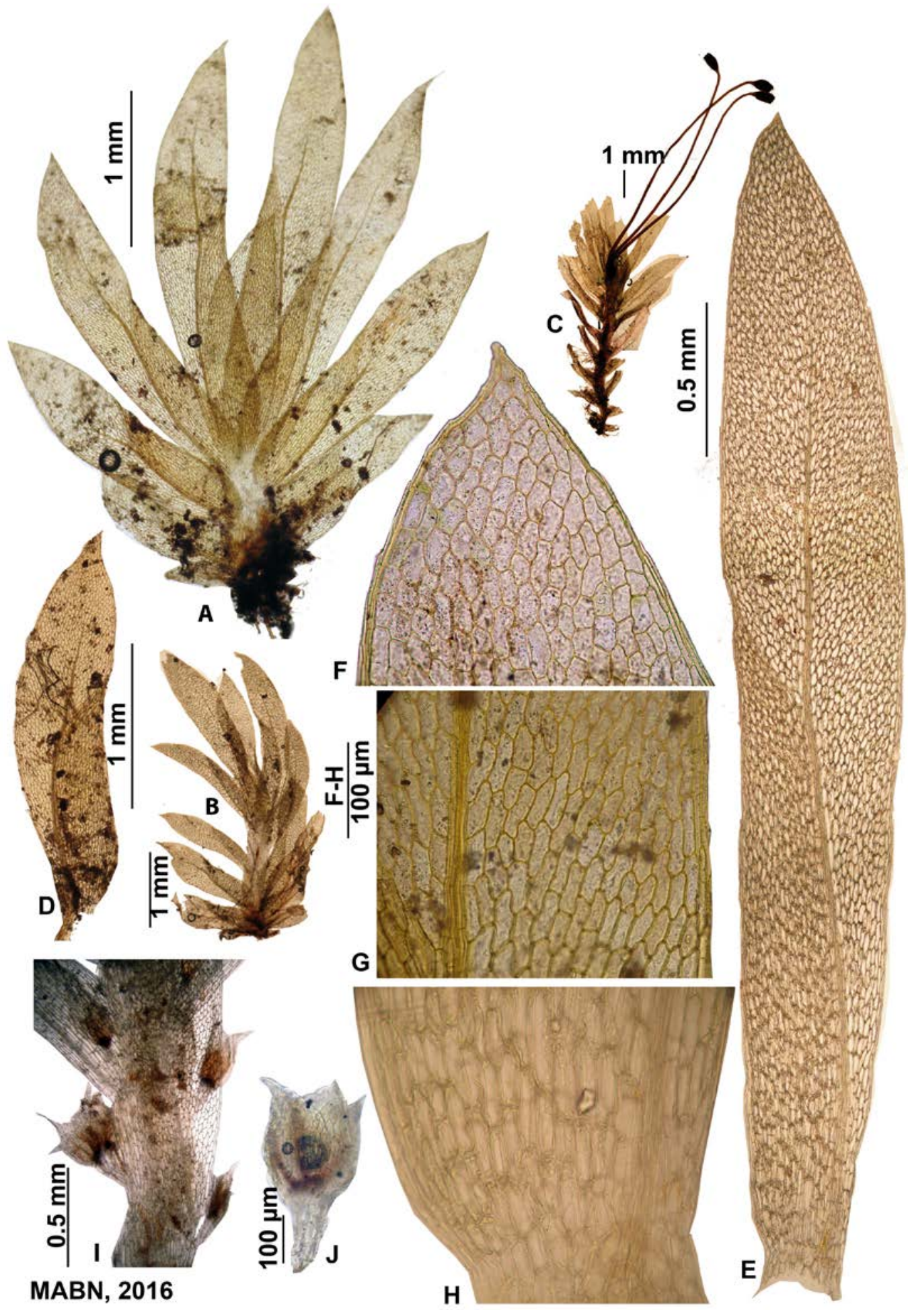


which cells were measured for the Neotropical monograph. More material from both continents is needed for taxonomic decisions. Pending this, the collection from São Tomé earlier reported as F. palmatus (Shevock et al. 2013) is here tentatively included in F. grandifolius.

SubSTRATE AND HABIT. On soil and wood. Growing in mats or scattered among other mosses.

НАвітAт. Often not indicated, forest including a riverine forest.

Elevation. Sea level to $230 \mathrm{~m}$ a.s.1.

Distribution. Endemic to West Africa. Known from west tropical Africa (Guinea; O'Shea 2006; Liberia, Nigeria, Sierra Leone, Togo; O'Shea 2006) and west central tropical Africa (Cameroon, Central African Republic, Gabon, São Tomé). Not common. New for Cameroon.

Also reported from Ivory Coast (Müller \& Schäfer-Verwimp 1999) but this specimen appeared to be $F$. flaccidus.

SELECTED SPECIMENS EXAMINED: CAMEROON, left bank of the Kèlè River, $29 \mathrm{~km} \mathrm{~N}$ of Eséka, Leeuwenberg 6019 B (L). - CENTRAL AFRICAN REPUBLIC [Oubangui], route Riv. Ngurro, près Wamiré, $60 \mathrm{~km}$ N of Bambari, 27 7-bri 1927, Tisserant 400 (PC-PV); Mbaïki, Station de la Maboké, Faurel 10 (PC, L). GABON, type specimen. - LIBERIA, Bakratown, Linder 853 (PC). - NIGERIA, Western Nigeria, Ijebu Prov., Omo (Shasha) Forest Reserve, Richards 3361 (L); Ijebu Prov., Ilugun/Alaro, McFarlane 513 (L); Ondo Prov., Oluwa Forest Reserve. McFarlane 250 (L); Benin Prov., Okomu Forest Reserve, Brenan (R 3886) (PC-PV). - SÃO TOMÉ, Island of Principe, Along trail towards the SW base of Pico Pagagaio from Rosa Santa Trinidade towards Rio Banzu, $01^{\circ} 36^{\prime} 45.6^{\prime \prime} \mathrm{N}, 07^{\circ} 23^{\prime} 14.7^{\prime \prime} \mathrm{E}$, Shevock 34650 (L). SIERRA LEONE, Freetown, Mount Aureol, Fourah Bay College Botany Garden, Harrington 700 (BM, with $F$. submarginatus).

Illustrations: Potier de la Varde (1926: f. 25, 1; 1929: fig. I, 1 \& II,1a, b; 1936: f. 4, 1 - same figure as 1926).
7. Fissidens minutifolius Broth. \& P. de la Varde Fig. 7

in P. de la Varde. Bull. Soc. Bot. France 73: 59, f. 25-2. 1926 - Protologue: [GABON], sur terre argileuse. Rive gauche de la Nounyé, entre Udendé et Labo, intimement mêlé au precedent [ $F$. grandifolius], mais beaucoup plus rare, XII 1924, Le Testu 5347 - LECTOTYPE (nov.) with label: sur argile, en forêt, rive g. de la Nyounyé, entre Undendé et Labo (intimement mêlé au precedent), 29 X-bri 1914, Le Testu 5347 (PC-PV PC0106510!, ISOLECTOTYPES: H-BR!; PC PC106509!).

Stem frondose, unbranched, $1.0-1.7 \times 1.5 \mathrm{~mm}$ (only fertile plants seen); rhizoids numerous, basal and from stem cortex, hyaline, \pm smooth; leaves close, 3-8 pairs, crispate when dry (impossible to revive without $\mathrm{KOH}$ ), elliptico-lanceolate to oblanceolate, acute-acuminate ending in pointed cell, $1.0-1.2 \times 0.2-0.3 \mathrm{~mm}, 4-6$ times as long as wide, limbate; limbidium on all laminae of all welldeveloped leaves, reaching leaf apex and fusing with costa, confluent at apex of vaginant laminae, becoming weak towards insertion of vaginant laminae, \pm reaching insertion of dorsal lamina, in mid dorsal laminae $18 \mu \mathrm{m}$ wide, 1-2-stratose (estimated), marginal; on vaginant lamina $22.5 \mu \mathrm{m}$ wide, lax, marginal; vaginant lamina $1 / 3-2 / 3$ of leaf length, at base about as wide as stem, almost closed; dorsal lamina narrowing towards insertion, reaching insertion, not decurrent; costa ex- to percurrent; mid dorsal laminal cells hexagonal, 30.0-52.5 × 15.0-18.0 $\mu \mathrm{m}$, smooth; mid vaginant laminal cells up to $60 \mu \mathrm{m}$ long. No gemmae seen.

Fertile parts, perigonia numerous, terminal on short, $\pm 0.35 \mathrm{~mm}$ long, bud-shaped plants at base of female plants, antheridia not seen; perichaetia terminal, perichaetial leaves 1.5-1.7 × $1.5 \mathrm{~mm}$, archegonia not seen; calyptra not seen. Sporophyte, seta 3.5-5.0 mm long, smooth, 1 per perichaetium; capsule erect to slightly inclined, $0.5 \times 0.45 \mathrm{~mm}$, with $c a 32$ columns of oblong exothecial cells with strongly thickened corners; peristome scariosustype, teeth at base $33.0-40.5 \mu \mathrm{m}$ wide; operculum

Fig. 6. Fissidens grandifolius Broth. \& P. de la Varde. A - vegetative stem with frondosely arranged leaves, B - stem with pinnately arranged leaves, C - sporophytic stem, D \& E - leaves, F - leaf apex, G - mid dorsal lamina, H - insertion of leaf, I - stalked axillary perigonia (leaves removed), J - stalked axillary perigonium (detail). A, B, D from McFarlane 513; C, G, J from Tisserant 400; F from type specimen; E, H, I from Faurel 10. 


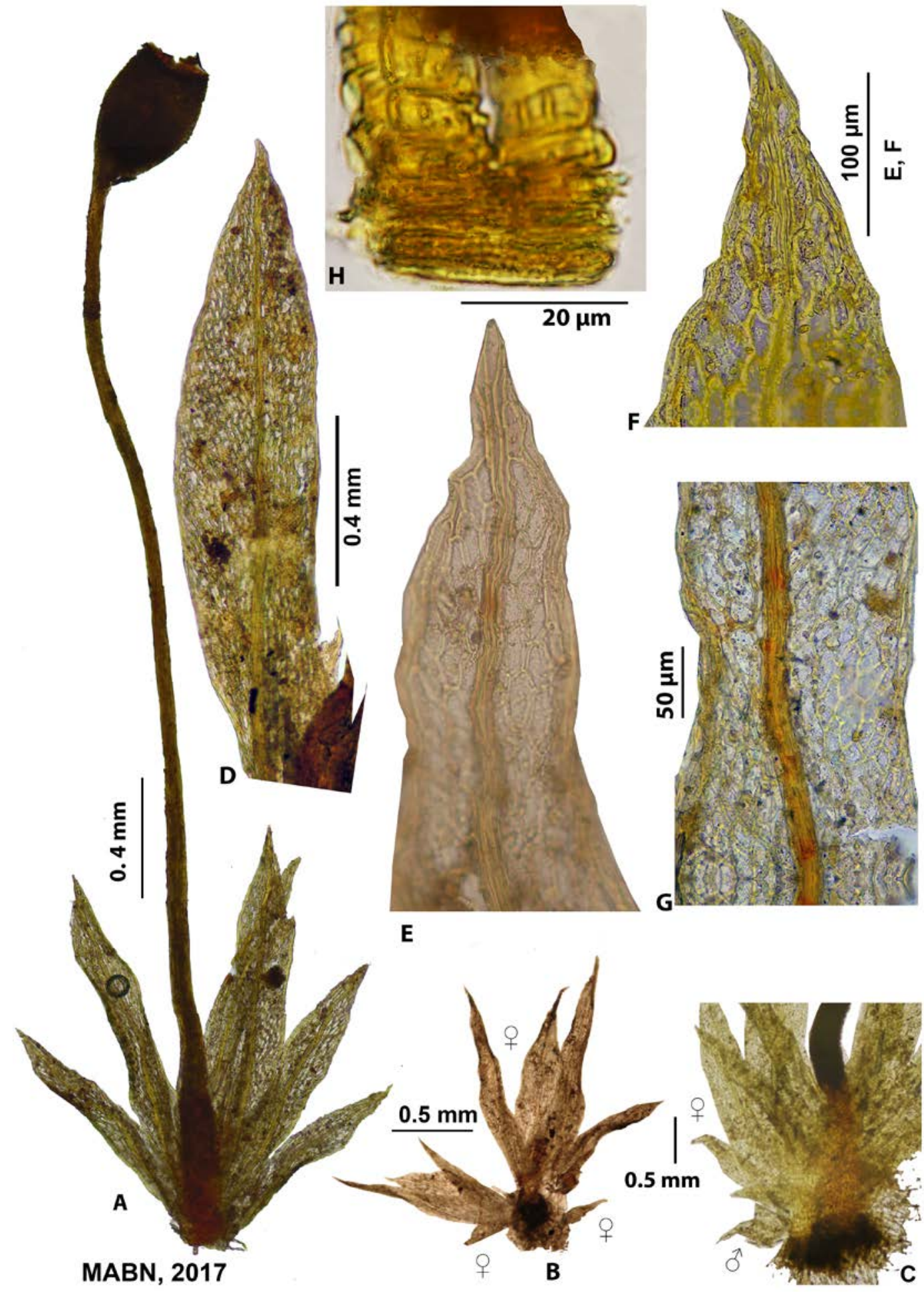


long-rostrate, $0.6 \mathrm{~mm}$ long; spores 9-12 $\mu \mathrm{m}$ long, smooth.

This tiny species is characterized by its frondose stems, over $30 \mu \mathrm{m}$ long laminal cells, completely limbate leaves, per- to excurrent costae, a scariosustype peristome and \pm 32 columns of exothecial cells on the capsule. It can be confused with F. flaccidus, which is larger and has shorter costae, and with F. zollingeri, which has half as large mid dorsal laminal cells. Fissidens minutifolius further resembles the subgenus Fissidens species F. aciphyllus Dixon and F. magnicellulatus Brugg.-Nann., which both differ in having a higher number of exothecial cells (40 columns or more) and a bryoides-type peristome. F. aciphyllus Dixon and F. magnicellulatus Brugg.-Nann. are very similar; and it cannot be ruled out that $F$. magnicellulatus will prove to be a perichaetial expression, with relatively large cells, of F. aciphyllus.

REMARKs. Due to the paucity of the available material, no cross sections were made. Features that can only be observed when leaves are removed (e.g., axillary nodules) are also excluded from the description.

HABITAT, SUBSTRATE AND HABIT. In forest on soil. Sparsely scattered among $F$. grandifolius plants, covered with dirt.

ElEVATION. Not indicated.

Distribution. A rare species, known from west-central tropical Africa (Gabon). Further reported from west tropical Africa (Togo and Nigeria O'Shea 2006).

SPecimens eXamined: GABON, types (PC-PV, H-BR); Pétsyalango, Le Testu s.n. (PC-0705948, PC-PV).

Illustration: Potier de la Varde (1926: f. 25, 2; 1936: f. 4, 2 - same figure as 1926).

\section{Fissidens nigerianus Bizot ex Brugg.-Nann.}

Fig. 8

J. Hattori Bot. Lab. 81: 170, 1997; Bizot, Rev. Bryol. Lichénol. 40: 101, pl. 1A, 1-2, 1974 - Protologue/
HOLOTYPE label: NIGERIA, on worm casts in deep shade in forest, $1700 \mathrm{ft}$, Garki Kurmi Abuja Prov., Minna, Jones 886 (PC!).

No vegetative stems observed, probably heterocaulous, perichaetial stems $0.60-1.50 \times$ 0.45-1.50 mm, unbranched, frondose; persistent filamentous protonema well developed; rhizoids basal, hyaline to pale brown, smooth; axillary nodules weakly differentiated; leaves imbricate, 2-5 pairs, slightly crispate when dry, lanceolate, acuminate-mucronate (perichaetial leaves), 0.7$1.6 \times 0.15-0.3 \mathrm{~mm}, 3.5$ times as long as wide, margins limbate, serrate where elimbate, limbidia frequently intramarginal on all laminae, extension and occurrence variable, typically present on all laminae, in perichaetial leaves not or \pm confluent at apex of vaginant laminae and \pm reaching leaf apex or ending well below it, in lower leaves less developed; often becoming ill-defined towards insertion of vaginant lamina; reaching insertion of dorsal lamina or ending well above it, in mid dorsal lamina $19 \mu \mathrm{m}$ wide, unistratose (estimated), marginal or intramarginal; on vaginant laminae 16-24 $\mu \mathrm{m}$ wide, unistratose (estimated), marginal or intramarginal by one row of cells; vaginant lamina $3 / 5$ of leaf length, at base narrower than stem, unistratose, slightly open; dorsal lamina tapering towards insertion, in perichaetial leaves reaching insertion to ending well above, not decurrent; dorsal and apical lamina unistratose; costa long excurrent in perichaetial leaves, per- to long excurrent in lower leaves; mid dorsal laminal cells hexagonal, large, 25.0-38.5 × 13.0-21.5 $\mu \mathrm{m}$, smooth, plane; mid vaginant laminal cells oblonghexagonal, 25.5-70.5 × 11.5-24.0 $\mu \mathrm{m}$, smooth, plane. Gemmae $150 \times 25 \mu \mathrm{m}$, monoseriate, growing from persistent protonema.

Fertile parts, perigonia terminal on small, $\pm 0.4 \mathrm{~mm}$ tall plants at base of perichaetial plants; antheridia $\pm 100 \mu \mathrm{m}$ long; perichaetia terminal; perichaetial leaves $0.7-1.2 \mathrm{~mm}$ long; archegonia $\pm 180 \mu \mathrm{m}$ long; calyptra $0.4 \mathrm{~mm}$ long, smooth.

Fig. 7. Fissidens minutifolius Broth. \& P. de la Varde. A - sporophytic stem, B - 3 young perichaetial stems, C - base of sporophytic stem with attached dwarf perichaetial and perigonial stems, D - leaf, E \& F - leaf apices, G - mid leaf, H - bifurcation of peristome tooth showing upper part of basal undivided part and basal part of two filaments. All from lectotype. 


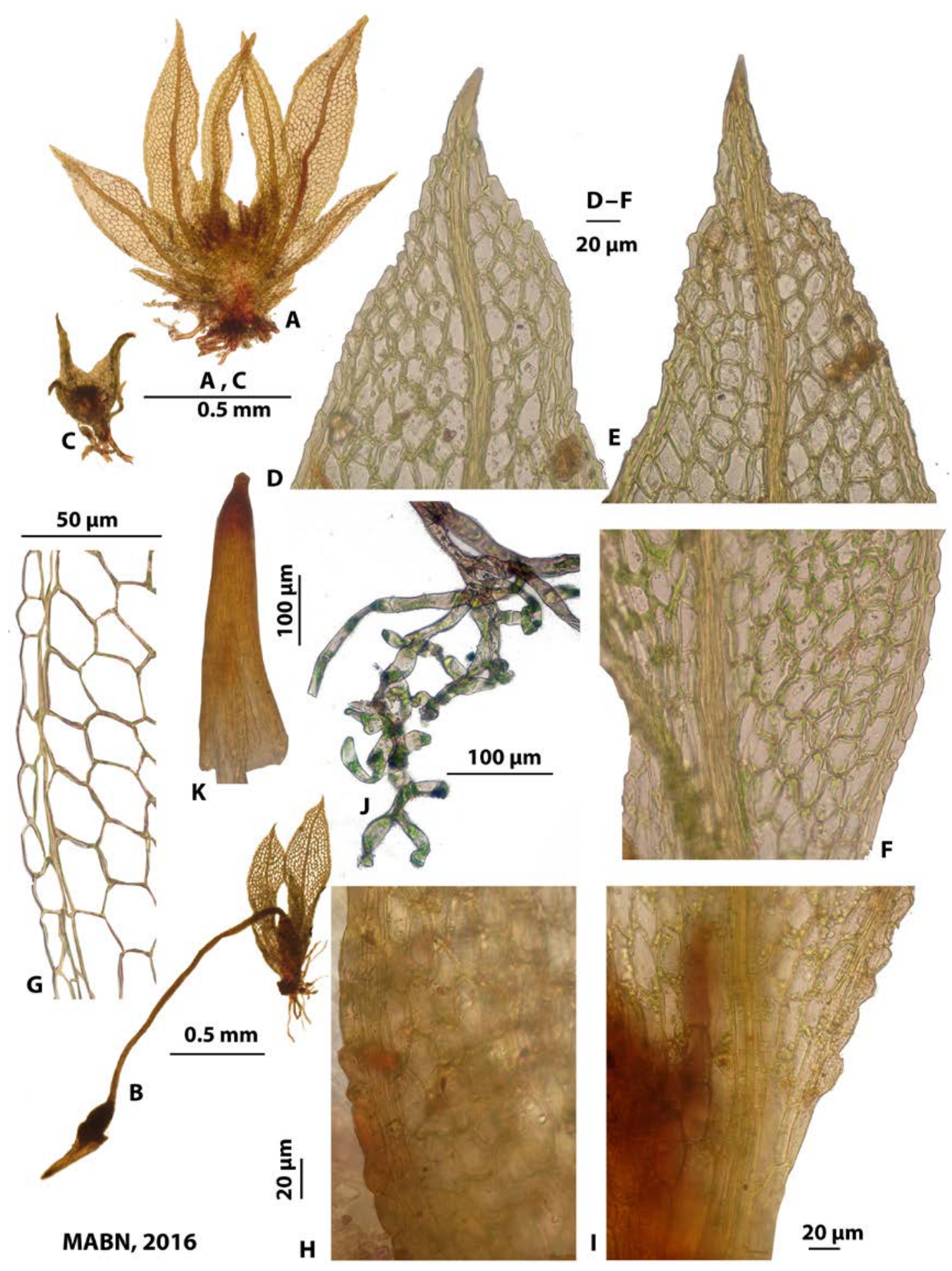


Sporophyte, seta 3.0-4.5 mm long, smooth, 1-2 per perichaetium; capsule \pm erect, $0.40-0.50 \times$ $0.25-0.35 \mathrm{~mm}$, with ca 32 columns of oblong exothecial cells; peristome details not observed, tooth base $41.5 \mu \mathrm{m}$ wide; operculum rostrate, $0.45 \mathrm{~mm}$ long; spores subglobose, 11-13 $\mu \mathrm{m}$ long, smooth.

This species is known from the type collection only. It is characterized by its limbate leaves with limbidia that are often intramarginal on all laminae, per- to excurrent costae, large cells (in mid dorsal lamina $25.0-38.5 \times 13.0-21.5 \mu \mathrm{m}$ ), and persistent protonemata with gemmae. Though intramarginal limbidia on vaginant lamina are fairly common in the Fissidentaceae, intramarginal limbidia on the dorsal and apical lamina are much rarer and thus have diagnostic value. Fissidens minutifolius resembles this species in having frondose stems and per- to excurrent costae, but is larger and has better-developed marginal limbidia. Fissidens nigerianus further resembles the Asian-Polynesian F. bogoriensis M. Fleisch. Both share short, frondose plants, limbidia that are often intramarginal on all laminae, large laminal cells, short perigonial plants at the base of perichaetial plants, and small spores [8-14(-16) $\mu \mathrm{m}$ in F. bogoriensis]. Fissidens nigerianus can be separated from this species by its per- to long excurrent costae and well developed persistent protonemata. It also resembles the Neotropical F. ornatus Herzog but that species is elimbate.

REMARK. Due to the paucity of the available material, no cross sections were made.

SubSTRATE AND HABITAT. Scattered on worm casts in deep shade in forest.

ELEVATION. $520 \mathrm{~m}$ a.s.1.

DistRIBUTION. Nigeria, known from the type locality only.

SPECIMEN EXAMINED: type specimen.

Illustration: Bizot (1974: pl. 1A, 1-2).
9. Fissidens zollingeri Mont.

Fig. 9

Ann. Sci. Nat. Bot., sér. 3, 4: 114. 1845 - Protologue: INDONESIA, Java, in terra turfosa, Zollinger 1604 (HOLOTYPE PC; ISOTYPE PC).

Fissidens vogelianus Mitt., Trans. Linn. Soc. London 23: 54, t. 5, f. 10. 1860 - Protologue: River Niger, Vogel - type label: Africa, Niger-expedition, Vogel s.n. (HOLOTYPE: NY, ISOTYPE PC); ISOTYPE: BM as Vogel 3.

Fissidens dubyanus A. Jaeger, Ber. Thätigk. St. Gallischen Naturwiss. Ges. 1874-1875: 107. 1876, new name for F. macrophyllus Welw. \& Duby in Duby, Mém. Soc. Phys. Genève 21: 223, t. 3, f. 3 a-e. 1870, hom. illeg. Protologue: ANGOLA, ad latera viarum cavarum in locis valde umbrosis inter Bango-Aquitamba et Bamba praesidii Golungo alto 1000-2000 ped. altit, in regno Angolensi, Welwitsch s.n. - LeCTOTYPE (designated by Bruggeman-Nannenga 1997) with label: Welwitsch, Iter Angolense 136 (BM!); ISOLECTOTYPE (PC!).

Fissidens obsoletidens Müll. Hal. in Besch., Ann. Sci. Nat. Bot., sér. 6, 9: 332. 1880 - Protologue: [NOSSI-BE], talus couverts sur bords de la mer, au-dessus du plateau de Helville, janvier 1850, Boivin (herb. Mus. Par.) and: Nossi-Bé, Nossi-Comba et Antourtour, sur les pierres, VIII 1879, Marie - LeCTOTYPe (designated by Bruggeman-Nannenga 1997) with label: Nossi-bé, talus couverts des bords de la mer au-dessus du plateau de Helville, I 1850, Boivin s.n. (PC!).

Fissidens platybryoides Müll. Hal., Flora 69: 505. 1886 - Protologue: [NIGERIA], Africa occid. Tropica, Old Calabar, in territorio fluminis Niger, in terra, 10 XI 1884, Mönkemeyer s.n. - LeCtOTYPe (designated by Bruggeman-Nannenga 1997) with label: Niger Gebiet, Alt Calabar, in terra, 11 (sic!) X 1885 (sic!), Mönkemeyer s.n. (H-BR); IsOLEctotyPe labeled: Afr. Occ. Old Calabar, in terra, 10 1885, Moenkemeyer s.n. (PC).

Fissidens tenuisetus Cardot, Rev. Bryol. 35: 64, 1908 - Protologue: DEMOCRATIC REPUBLIC OF THE CONGO, [Congo belge], Kisantu, sur la terre et le bois pourri, H. Vanderyst (sic!), 1906 - TyPE label: Congo belge, Kisantu, 1906, Vanderijst (sic!) s.n. (HOLOTYPE: PC!; ISOTYPE: H-BR).

Fissidens brachycaulon Broth. in Mildbr., Wiss. Ergebn. Deut. Zentr.-Afr. Exped., Bot. 2: 143, t. 11, f. 7. 1910 - Protologue/type label: [TANZANIA], Bukoba-

Fig. 8. Fissidens nigerianus Bizot ex Brugg.-Nann. A - archegonial stem, B - sporophytic stem, C - perigonial stem, D - apex of stem leaf, E - apex of perichaetial leaf, F - mid leaf, $\mathrm{G}$ - mid dorsal lamina with intramarginal limbidium, $\mathrm{H}$ - margin of vaginant lamina, I - insertion of dorsal lamina, $\mathrm{J}$ - persistant protonema, $\mathrm{K}$ - calyptra. All from type specimen. 
Bezirk, Buddu-Wald, auf lehmigen Waldboden, VI 1907, Mildbraed 243 (HOLOTYPE: H-BR).

Fissidens herpetineuron Broth. \& P. de la Varde in P. de la Varde, Arch. Bot. Bull. Mens. 3: 2, f. I, 2 and f. II, 2. 1929 - Protologue: CENTRAL AFRICAN REPUBLIC [Oubangui], sur terre, marais près d'Ippy, Tisserant s.n. - LeCtotyPe (designated by Bruggeman-Nannenga 1997) with label: Oubangui, sur terre, marais près d'Ippy, 19 VI 1928, Tisserant 473 (PV 3073) (PC-PV).

Stem without or with weak central strand, hardly heterocaulous, unbranched to frequently branched, 2.4-5.0 × 1.7-3.5 mm; rhizoids basal and from basal stem cortex, brown, smooth; axillary nodules differentiated or not; leaves frondosely to pinnately arranged, crowded to distant, 3-12 pairs, crispate when dry, elliptical to elliptic-lanceolate or obovate-lanceolate with acute to acute-acuminate to mucronate apex, $(1.1-) 1.5-2.5(-3.0) \times$ $0.2-0.5 \mathrm{~mm}, 3.0-6.0(-7.5)$ times as long as wide, limbate on all laminae of all leaves; limbidia reaching leaf apex, often becoming indistinct at apex or sometimes ending below it, confluent at junction of vaginant laminae, reaching insertion of vaginant lamina, reaching insertion of dorsal lamina or ending slightly above, in mid dorsal lamina 6-19 $\mu \mathrm{m}$ wide, (1-)2-stratose; on vaginant laminae 15-40 $\mu \mathrm{m}$ wide, $1-2(-3)$-stratose, marginal to weakly intramarginal near insertion; vaginant laminae $1 / 5-2 / 3$ of leaf length, at base narrower than stem, closed, unistratose; dorsal laminae tapering below, straight to slightly rounded at base, reaching insertion or not, not decurrent; dorsal and apical lamina unistratose; costa percurrent to longexcurrent, bryoides-type; mid dorsal laminal cells hexagonal, variable in size $(6.5-) 11.0-27.0 \times 4.5-$ 14.5(-19.5) $\mu \mathrm{m}$, smooth, plane; mid vaginant laminal cells hexagonal to oblong, (10.0-)14.0-36.5 × (5.0-)9.0-16.0(-18.5) $\mu \mathrm{m}$; basal vaginant laminal cells oblong, (18-)34.5-81(-94.5) × (6.5-)10.5$24.5(-31) \mu \mathrm{m}$. Gemmae on short axillary rhizoids, uniseriate multicellular, once in terminal cluster on short stalks, $0.6-0.7 \times 0.1 \mathrm{~mm}$, rare.
Fertile parts. Perigonia and perichaetia on separate stems or on same stem, synoicia rare; perigonia terminal on $0.85-3.00 \mathrm{~mm}$ long stems, also on budlike, $0.6-1.1 \mathrm{~mm}$ long branches; antheridia 120-300 $\mu \mathrm{m}$ long; perichaetia terminal on stems and/or branches; perichaetial leaves slightly longer than stem leaves, 1.1-3.0 mm long; archegonia 200-400 $\mu \mathrm{m}$ long; calyptra $0.6-0.8 \mathrm{~mm}$ long, smooth. Sporophyte, seta 3.5-6.5 mm long, smooth, 1-2 per perichaetium; capsule erect to suberect, $0.40-0.90 \times 0.20-0.45 \mathrm{~mm}$, with $\mathrm{ca} 32$, oblong or quadrate-oblong exothecial cells with thin walls and thickened corners; peristome scariosus-type, tooth base 33-53 $\mu \mathrm{m}$ wide; operculum rostrate, $0.55-0.80 \mathrm{~mm}$ long; spores (7.0-)9.0$14.5 \times(5.0-) 8.0-12.5 \mu \mathrm{m}$, papillose to smooth.

Fissidens zollingeri is a heterogeneous species. Features common to all specimens are the limbidia on all laminae of all leaves, per- to excurrent costa, smooth, medium-sized laminal cells, and when sporophytes are present \pm 32 columns of exothecial cells around the capsule. The combination of this last character with limbate leaves and smooth, medium-sized cells is rare in the Fissidentaceae. Stems can be short and frondose with imbricate leaves, but collections with longer stems and pinnately arranged leaves are not rare. The juxta-costal cells of the vaginant laminae are typically large and clear (usually easily visible at $5 \times$ magnification) and conspicuously inflated (Fig. 9D, H, I); hyaline axillary nodules are present or not. In the majority of specimens the limbidia reach the leaf apex and the insertion of the dorsal lamina, but in a fair number the limbidia become weak towards the leaf apex or end below it and/or end above the insertion of the dorsal lamina. Mid dorsal laminal cells vary in size at $(6.5-) 11.0-27.0 \times 4.5-14.5(-19.5)$ $\mu \mathrm{m}$. Cell size differs greatly between specimens. In most specimens the mid dorsal laminal cells are $\pm 16 \mu \mathrm{m}$ long, but collections with smaller or larger cells (though always less than $30 \mu \mathrm{m}$ ) are regularly found. Specimens with small cells

Fig. 9. Fissidens zollingeri Mont. A - vegetative stem, B - 2 perigonial stems, C - sporophytic stem, D - leaf, E \& F - leaf apices, $\mathrm{G}$ - mid leaf, $\mathrm{H}$ - leaf insertion, I - cross section of vaginant lamina with inflated cells, J - cluster of gemmae. A, F, H from Richards 3840; B, D-E, G, I from Pócs 97120; C from Müller E 209; J from Kovas s.n. 


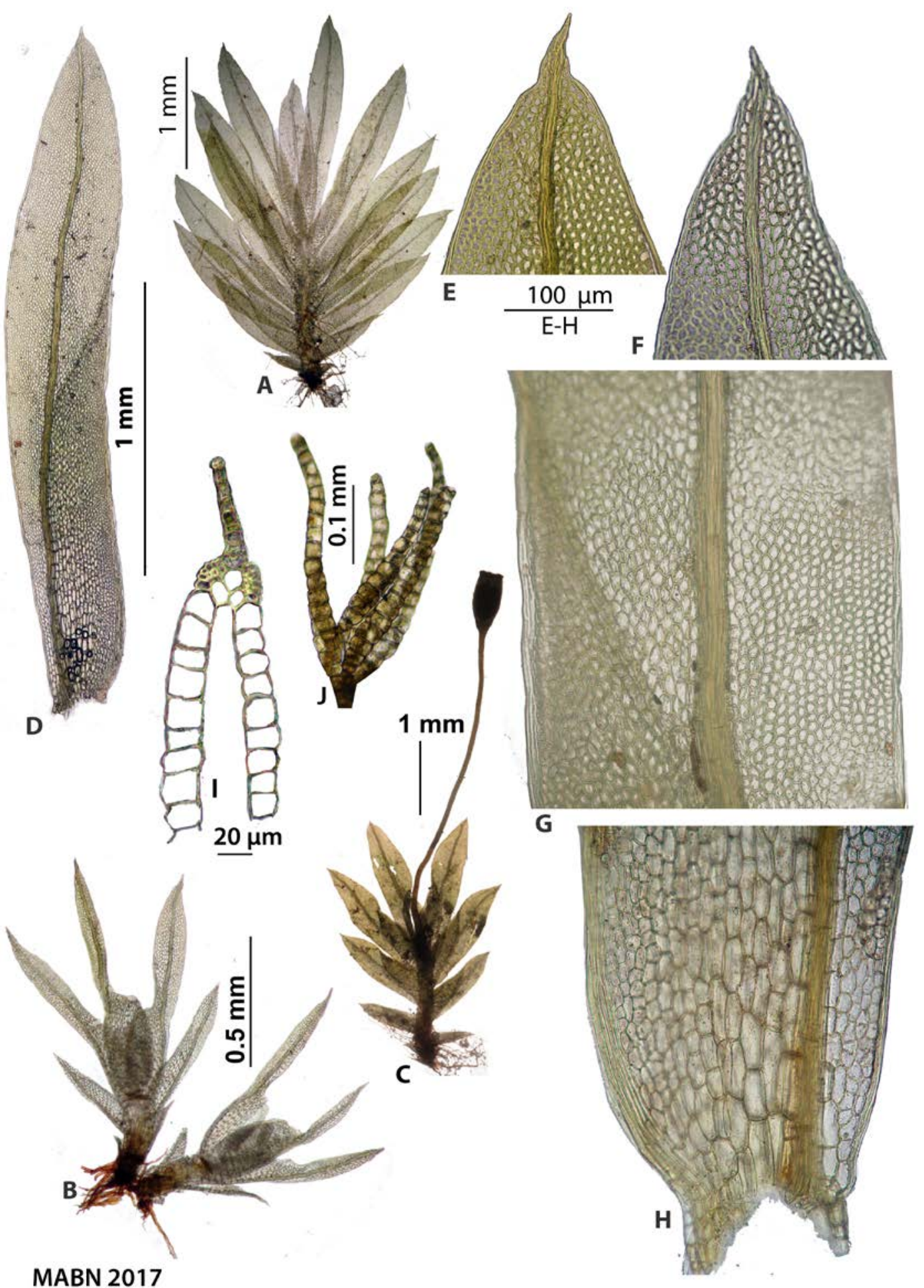


include, for example, Pócs $8436 / A A$ (mid dorsal laminal cells $6.5-11.5 \times 5.0-8.0 \mu \mathrm{m}$ ) and Dilg $1-3$ [mid dorsal laminal cells (6.0-)9.0-11.5(-12.5) $\times$ (5.0-)6.0-8.5(-10.0) $\mu \mathrm{m}]$. Larger plants tend to have larger cells and - rather surprisingly, because typically large plants have better-developed limbidia - more often have elimbate leaf apices, but this correlation is weak. The African $F$. minutifolius resembles frondose specimens of $F$. zollingeri in having limbate leaves, per- to excurrent costae and smooth laminal cells, but it has larger, 30.0-52.5 $\times$ 15.0-18.0 $\mu \mathrm{m}$, mid dorsal laminal cells. Fissidens zollingeri can further be confused with $F$. biformis Mitt. (=F. angustifolius Sull.), which is distinct with its mammillose laminal cells, and with species of subgenus Fissidens. With the latter it shares limbate leaves and smooth laminal cells, but species of subgenus Fissidens have sporophytes with 40 or more columns of exothecial cells around the theca, and also bryoides-type peristomes. In tropical Africa the subgenus Fissidens species with which $F$. zollingeri is most likely to be confused is F. curvatus Hornsch. Apart from the differences in sporophytic characters, this species is distinct for being heterocaulous (that is, having vegetative stems that differ markedly from shorter perichaetial ones).

SubSTRATE AND Habit. Most often on soil, frequently on rocks, rarely on wood (twigs, wood and bark) or termite mounds. Growing in mats, small tufts, or scattered.

Habitat. On shady road edges and stream banks in forests (lowland and montane rainforests, once in semi-deciduous forest, once in riverine forest), less often in savannas or cultivated areas (plantations, gardens, etc.). Frequently found in wet places (near rivers, springs and cascades), occasionally submerged.

Elevation. In Africa 0-1750(-2100) m a.s.l.; in the Neotropics up to to $3360 \mathrm{~m}$ a.s.l. (Pursell 2007).

Distribution. Common and widespread. African distribution: west tropical Africa (Benin, Gambia, Ghana, Guinea, Ivory Coast, Nigeria, São Tomé and Príncipe); west-central tropical Africa (Cameroon, Democratic Republic of the Congo,
Central African Republic, Gabon); east tropical Africa (Kenya; Kis 1985; Tanzania, Uganda); south tropical Africa (Angola, Zambia; Kis 1985) and western Indian Ocean (Comoro islands, Madagascar, Réunion, Rodriguez, Seychelles). New for Ghana. Outside Africa known from the Neotropics, Asia and Oceania.

SELECTED SPECIMENS EXAMINED: ANGOLA, type of Fissidens dubyanus (BM, PC). - BENIN, Forêt classée de la Lama, $6^{\circ} 55^{\prime}-7^{\circ} \mathrm{N}, 2^{\circ} 04^{\prime}-2^{\circ} 12^{\prime} \mathrm{E}$., Dilg 1.3 (L). - CAMEROON, Southwest, slopes of Mount Koupe, $4^{\circ} 50^{\prime} \mathrm{N}, 0^{\circ} 43^{\prime} \mathrm{E}$, Magill \& Crosby 9063 (MO); Johan Albrecht Höhe, Standt 698 (H-BR); Bipinde, Urwaldgebiet, Zenker 2614 (H-BR, L); Yaoundé, Universität-Yaoundé, Frahm MD100 (L, BONN); Div. Kumba, Bopo, S. Bakundu Forest Reserve, Richards 4034 (PC-PV, L). CENTRAL AFRICAN REPUBLIC, Berberati, Tisserant $M 826$ (PC-PV); type of $F$. herpetineuron (PC-PV); COMORES, Ndzuani (Anjouan), NW coast near Quani, Pócs 9168/Q, p.p., with F. flaccidus (EGR, L). - DEMOCRATIC REPUBLIC OF THE CONGO, Prov. Kivu, Pinga, $1^{\circ} 0^{\prime} \mathrm{S}$. Br; $28^{\circ} 43^{\prime} \mathrm{O}$. L, F. Müller Z 211 (L, DR); $1^{\circ} 0^{\prime} \mathrm{S}$. Br; $28^{\circ} 43^{\prime} \mathrm{O}$. L., F. Müller Z 212 and Z.222 (both $\mathrm{DR}, \mathrm{L}$ ); $1^{\circ} 0^{\prime} \mathrm{S}$. Br; $28^{\circ} 43^{\prime} \mathrm{Ö}$. L, F. Müller Z 228 (DRE, L); Congo belge, LeRoy $36 A$ (PC-PV). - EQUATORIAL GUINEA, BIOKO, $3^{\circ} 21^{\prime} \mathrm{N}, 8^{\circ} 42^{\prime} \mathrm{E}$, F. Müller B 744, p.p., with $F$. crispulus, asplenioides and androgynus (DR, L). - GABON, Moungoumou Poubi, Le Testu 3991 (PC-PV, L); Moyandi, Le Testu 2220, p.p. (H-BR). THE GAMBIA, Kombo East District, Pirang, $c a 1 \mathrm{~km}$ SE of Bonto. $13^{\circ} 16^{\prime} \mathrm{N}, 16^{\circ} 3^{\prime} \mathrm{W}$, Perry 9858 (NMW, L); Kombo North District, Abuko Nature Forest Reserve, $13^{\circ} 23^{\prime} \mathrm{N}, 16^{\circ} 38^{\prime} \mathrm{W}$, Perry 9852 (NMW, L). - GHANA, Kumasi, Kovács s.n. (PC, a few stems in L). - GUINEA [Guinea gall.], Pita, Pobeguin 1823 (H-BR); DjallonTimbo, Pobeguin 306, p.p. mixed with F. flaccidus (L); $2 \mathrm{~km}$ westlich der Grenze zur République Côte d'Ivoire, Porembski 202 (BONN, L). - IVORY COAST, Umgebung der Ortschaft Gouedie (= Gouele), $24 \mathrm{~km}$ NW of Man. $7^{\circ} 32^{\prime} \mathrm{N}, 7^{\circ} 45^{\prime} \mathrm{W}$, F. Müller E193 (DR, L); $30 \mathrm{~km}$ südlich von Séguéta, Granitinselberg $(\mathrm{Nr}$ IB22), Porembski 297 (BONN, L); Ferkessedougou, im Stadtbereich beim Hotel Auberge de la Reserve, $9^{\circ} 35^{\prime} \mathrm{N}$, $5^{\circ} 12^{\prime} \mathrm{W}$, F. Müller E 209 (DR, L). - MADAGASCAR, Nossi-bé, lectotype F. obsoletidens (PC); Nossi-bé, Marie s.n. (PC, H-BR); Nossi-Comba, Marie s.n. (PC). - NIGERIA, Oyo State, Ibadan, McFarlane 140, 227, 465 (all: L, private herbarium McFarlane); Ogun [Ijebu] State, Ijebu-Ode, McFarlane 94, 99, 136, 171, 174, 195, 238, 242, 272, 280, 281, 506 (all: L, private herbarium McFarlane); Ondo Prov., Oluwa Forest Reserve, McFar- 
lane 254 (L, private herbarium McFarlane); Div. Akure, Richards 3808 (PC-PV). - RÉUNION, Anse des Cascades, $21^{\circ} 10^{\prime} \mathrm{S}, 55^{\circ} 50^{\prime} \mathrm{E}$, Bruggeman-Nannenga 11014 (L, REU). - RODRIGUEZ, Balfour s.n. (NY). - SÃO TOME \& PRINCIPE, Island of Príncipe, below roça Belo Monte Resort, Lat/Long NAD 83: $01^{\circ} 41^{\prime} 13.1^{\prime \prime} \mathrm{N}$, $07^{\circ} 26^{\prime} 34.8^{\prime \prime} \mathrm{E}$, Shevock et al. 49767 (L, mixed between F. grandifolius). - SEYCHELLES, MAHÉ, path near Botanical Gardens, Norkett 16880 (BM); banks of La Misère Road, Norkett 17025 (BM, L); PRASLIN, path near Grande Anse, Norkett 18349 (BM). - TANZANIA, Dar es Salaam Universtity campus by Mulakuwa stream course, above University Road. Wingfield 2776 A (MO); Morogoro Mts, N valley of Lupanga, behind Kigurunyembe Missin and TTC, $6^{\circ} 50.4^{\prime} \mathrm{S}, 37^{\circ} 42^{\prime} \mathrm{E}$, Pócs 97220/A, p.p. mixed with Fissidens specs. (EGR, L); Nguru Mts in Morogoro District, Mt Kanga N of Turiani, Pócs 90110/L (EGR a few mixed with F. crispulus Brid.); East Usambara Mts, around Amani Medical Research Center, Pócs 87115/N (EGR, L); West Usambara Mts, forest in entrance of gorge of the SW escarpment, above Mazinde village, Pócs 8436/AA, AG (EGR, L). - UGANDA, Hoima District, Itohya Forest, $1.5 \mathrm{~km}$ SW of Muntene village, $25 \mathrm{~km}$ WSW of Hoima Town. $1^{\circ} 18.2^{\prime} \mathrm{N}, 31^{\circ} 3.4^{\prime} \mathrm{E}$., Lye \& Pócs 97120/O (EGR); Mpanga Forest Reserve, Kampala, Jones 600 (E, BM, L, cum spor.); Mpigi, Mpanga Forest Nature Reserve, $0^{\circ} 12^{\prime} \mathrm{N}, 32^{\circ} 18^{\prime} \mathrm{E}$, Wigginton U 5249A (E, L); Masindi District, Budongo Forest, near Sonso, $1^{\circ} 43^{\prime \prime} \mathrm{N}, 31^{\circ} 31^{\prime} \mathrm{E}$, Wigginton U 3161c (E, L); Kabarole, Kibale Forest, Kanyawara (S), $0^{\circ} 33^{\prime} \mathrm{N}, 30^{\circ} 21^{\prime} \mathrm{E}$, Bates U $8644 A$ (E, L).

Selected illustrations: Bruggeman-Nannenga (2006b: fig. 26), Bruggeman-Nannenga \& Arts (2010: fig. 38), Bruggeman-Nannenga (2011: fig. 44), Iwatsuki \& Suzuki (1982: pl. XIII), Pursell (1994: fig. 51; 2007: fig. 123, 1-u).

\section{TYPE MATERIAL NOT AVAILABLE FOR STUDY}

Fissidens pechueli (Müll. Hal.) Paris, Index Bryol.: 480. 1896 - Conomitrium pechueli Müll. Hal., Flora 69: 503. 1886 - Protologue/TyPE: Africa occid. Tropica [Democratic Republic of the Congo], in rivulo Loa inter Vivi et cataracta "Yélala" fluminis Congo, 1 Junio 1884: Dr. Pechuël-Lösche cum Marchantia sterili collegit in arena quartzitica.

The protologue is of a species with large cells, limbate leaves, and costae ending far below the apex. It is excluded since the type could not be located.
Acknowledgements. I am grateful to Dr. Jessica E. Beever for discussions and for the gift of a specimen of F. dealbatus, to the curators of BM, H, L, M, NY and PC for the loan of specimens, to Len Ellis (BM) who, as always, has been helpful in many ways, and to the reviewers, Dr. Jessica E. Beever and Dr. Frank Müller, for helpful and stimulating remarks and suggestions on the manuscript.

\section{REFERENCES}

Beever J. E., Malcolm B. \& Malcolm N. 2002. The moss genus Fissidens in New Zealand an illustrated key. MicroOptics Press, Nelson N.Z.

Beever J. E. 2014. Fissidentaceae. In: P. B. Heenan, I. BreitWIESER \& A. D. WiLton, Flora of New Zealand-Mosses Fascicle 8. Manaaki Whenua Press, Lincoln. http://dx.doi. org/10.7931/J24Q7RWN.

Bizot M. 1974. Enumeratio muscorum novarum. Rev. Bryol. Lichénol. 40: 101-138.

Bızot M. \& Pócs T. 1979. East African Bryophytes, III. Acta Bot. Acad. Sci. Hung. 25(3-4): 223-261.

Bruggeman-Nannenga M. A. \& Pursell R. A. 1995. Notes on Fissidens V. Lindbergia 20: 49-55.

Bruggeman-Nannenga M. A. 1997. Notes on Fissidens VI. New synonyms, new combinations and validation of some names. J. Hattori Bot. Lab. 81: 155-173.

Bruggeman-Nannenga M. A. 2006a. Bryophyte Flora of Uganda 6 Fissidentaceae (Part 1). J. Bryol. 28: 53-62.

Bruggeman-NAnnenga M. A. 2006b. Bryophyte Flora of Uganda 6 Fissidentaceae (Part 2). J. Bryol. 28: 139-148.

Bruggeman-Nannenga M. A. 2009. Notes on Fissidens VIIIX. J. Bryol. 31: 106-116.

Bruggeman-Nannenga M. A. 2011. Order Fissidentales. In: M. J. JANSEN-JACOBS (ed.), Flora of the Guianas, series C: Bryophytes, fascicle 2. Musci 4: 37-104. Royal Botanic Gardens, Kew.

Bruggeman-Nannenga M. A. 2013a. Fissidens tamaspocsii and F. magnicellulatus spp. nov. from eastern Africa and validation of $F$. cyatheicola. Lindbergia 36: 9-14.

Bruggeman-Nannenga M. A. 2013b. Subgenus Fissidens in tropical Eastern Africa with emphasis on the Tanzanian collections by Tamas Pócs. Polish Bot. J. 58(2): 369-417.

Bruggeman-Nannenga M. A. \& ArTs T. 2010. A revision of the Fissidentaceae (Musci) of La Réunion (including all species known from Mauritius and Rodriguez). J. Bryol. 32: $170-207$.

Bruggeman-Nannenga M. A., Manjula K. M. \& Manju C. N. 2016. Fissidens enervis (Fissidentaceae; Bryophyta) new to Asia. Lindbergia 39: 29-32. 
Chuah-Petiot M. S. 2003. Mosses, liverworts and hornworts of Kenya. An illustrated guide with descriptions and figures of over 300 species and keys for identification. ChuahPetiot, Nairobi.

EDDy A. 1988. A handbook of Malesian mosses vol. 1 (Sphagnales - Dicranales). British Museum of Natural History, London.

Ignatov M. S, Suzuki T. \& Cherdantseva V. Ya. 2007. Fissidens hyalinus (Fissidentaceae, Bryophyta), a new species for Russia. Arctoa 16: 123-126.

Hylander K., Nemomissa S. \& Hedenäs L. 2017. Mosses of southwest Ethiopian montane forests - notes on their occurrence pattern and many new country records, J. Bryol. DOI: $10.1080 / 03736687.2017 .1329793$

IwATSUKi Z. \& SuZuki T. 1982. A taxonomic revision of the Japanese species of Fissidens (Musci). J. Hattori Bot. Lab. 51: 329-508.

IwATSUKI Z. \& SUZUKI T. 1995 Fissidens (Musci, Fissidentaceae) in Vanuatu (New Hebrides) collected by Dr. M. Higuchi. Fragm. Florist. Geobot. 40: 153-158.

Kis G. 1985. Mosses of South-East Tropical Africa. Vácrátót, Hungary.

Li Z.-H. 1985. A revision of the Chinese species of Fissidens (Musci Fissidentaceae). Acta Bot. Fenn. 129: 1-65.

Magill R. E. 1981. Sphagnaceae to Grimmiaceae. Part 1, Mosses. In: O. A. LeISTNER (ed.), Flora of Southern Africa, pp. 1-291. Botanical Research Institute, Pretoria.

MüLler F. \& SchÄFER-Verwimp A. 1999. New bryophyte taxon records for tropical countries III. Trop. Bryol. 16: 195-202.

MÜLleR F. 2015. About 150 years after Welwitsch - a first more extensive list of new bryophyte records for Angola, Nova Hedwigia 100(3-4): 487-505.

O'Shea B. J. 2006. Checklist of the mosses of sub-Saharan Africa (version 5, 12/06). Tropical Bryology Research Reports 6: 1-152.

Potier de la VArde R. 1926. Mousses nouvelles de l'Afrique tropical française. (Diagnoses préliminaires). (3-de note). Bull. Soc. Bot. France 73: 57-63.
Potier de LA VARde R. 1929. Additions aux Mousses de l'Oubangui. Arch. Bot. Bull. Mens. 3: 1-9.

Potier de la Varde R. 1936. Mousses de Gabon. Mém Soc. Natl. Sci. Nat. Math. Cherbourg 42: 1-270.

Potier DE la VARde R. 1937. Herborisations dans la région de Bocaranga (Oubangui). Rev. Bryol. Lichénol. 9: 194-209.

Pursell R. A. 1994. Fissidentales. In: A. J. Sharp, H. Crum \& P. M. Eckel (eds), The Moss Flora of Mexico. Part one. The New York Botanical Garden, New York.

Pursell R. A. 1997. Taxonomic Notes on Neotropical Fissidens. II. An addendum, Bryologist 100: 193-197.

Pursell R. A. 2007. Fissidentaceae. Flora Neotropical Monograph 101. The New York.

Pursell R. A. \& Bruggeman-Nannenga M. A. 2004. A revision of the infrageneric taxa of Fissidens. Bryologist 107: 1-20.

Salmon E.S., 1899. On the genus Fissidens. Ann. Bot. (London) 13: 103-130, Pl. V-VII.

Schultze-Motel W. 1975. Katalog der Laubmoose von WestAfrika. Wildenowia 7: 473-535.

Seppelt R. D. \& Stone I. G. 2016. Australian Mosses Online 70. Fissidentaceae. Australian Biological Resources Study, Canberra. Version 19 January 2016. http://www.anbg.gov. au/abrs/Mosses_online/70_V2_Fissidentaceae.html.

Shevock J. R., Pursell R. A., Garcia C. A., BruggemanNannenga M. A. \& Sérgio C. 2013. The genus Fissidens in the Republic of São Tomé and Príncipe, Gulf of Guinea, West Africa. J. Bryol. 35(3): 197-205.

Sim T. R. 1926. The bryophyta of South Africa. Trans. Roy. Soc. South Africa 15: 1-475.

Stone I. G. 1986. A comparison of the species of Fissidens subgenus Aneuron in Australia. J. Bryol. 14: 319-325.

Stone I. G. 1988. Fissidens maceratus Mit. (synonym F. splachnobryoides Broth.). J. Bryol. 15: 117-122.

SuZUKi T. \& IwaTsuki Z. 2007. A new approach to the infrageneric classification of the genus Fissidens (Fissidentaceae, Bryopsida). Hikobia 15: 67-85.

Suzuki T. \& Iwatsuki Z. 2012. Keys to the subgenera, sections, and species of Fissidens in Japan. Hattoria 3: 49-56. 